\title{
Gazdaságpolitikai ágak közötti koordináció(?) az euroövezetben*
}

\author{
Lehmann Kristóf - Nagy Olivér - Szalai Zoltán - H. Váradi Balázs
}

Tanulmányunkban a gazdaságpolitika két alappillére, a monetáris politika és a fiskális politika közötti koordinációt mutatjuk be az euroövezet vonatkozásában. Az elmúlt három évtizedben érdemben lassult az eurozóna növekedése, ezáltal jelentősen eltávolodott az övezet gazdasága a maastrichti kritériumok logikájától. Emellett rendszerszintű problémára utal egy közös, eurozóna-szintű költségvetés hiánya is, illetve hogy az olykor egymással is ellentmondásos szabályok nem veszik figyelembe a szektorális összefüggéseket. A nehézségek az utóbbi években látványosabbá váltak, miután az ultralaza monetáris politika sem tudta érdemben stimulálni a növekedést. A kedvezőtlen folyamatot a maastrichti kritériumok mintájára megalkotott fiskális szabályoknak megfelelni igyekvő, övezeti szinten összességében szigorúnak tekinthetö fiskális politika felerősítette. Az utóbbi hónapokban az Európai Központi Bank döntéshozói között is nyílt vita alakult ki a gazdaságpolitikai ágak szerepét illetően. A jelenlegi politikai és jogi keretek között a monetáris kondíciók lazítására meglehetösen korlátozott mozgástér maradhat az EKB számára. Mindezek fényében felmerülhet az aktivabb fiskális politika szükségessége az euroövezet gazdaságának élénkítésében, ami azonban tovább élezheti az egyes tagországok gazdaságpolitikusai közötti vitát.

Journal of Economic Literature (JEL) kódok: E52, E62, E63, F45

Kulcsszavak: monetáris politika, fiskális politika, gazdaságpolitikai koordináció, maastrichti kritériumok

\footnotetext{
* A jelen kiadványban megjelenő írások a szerzők nézeteit tartalmazzák, ami nem feltétlenül egyezik a Magyar Nemzeti Bank hivatalos álláspontjával.

Lehmann Kristóf a Magyar Nemzeti Bank igazgatója. E-mail: lehmannk@mnb.hu Nagy Olivér a Magyar Nemzeti Bank elemzője.E-mail: nagyoli@mnb.hu

Szalai Zoltán a Magyar Nemzeti Bank vezető közgazdasági szakértője. E-mail: szalaiz@mnb.hu

H. Váradi Balázs a Magyar Nemzeti Bank főosztályvezetője.E-mail: varadib@mnb.hu

A szerzők köszönetet mondanak Bagdy Ábelnek, Balázs Flórának és Füstös Krisztinának értékes észrevételeikért és aktív hozzájárulásukért a tanulmány elkészítéséhez. A fennmaradó hibák a szerzőket terhelik.

A magyar nyelvű kézirat első változata 2019. december 20-án érkezett szerkesztőségünkbe.

DOI: http://doi.org/10.25201/HSZ.19.1.3764
} 


\section{Bevezetés}

Az elmúlt három évtizedben érdemben lassult az eurozóna növekedése és az infláció is alacsony szinten stabilizálódott. Ezzel jelentősen eltávolodott az övezet gazdasága az 1992-ben elfogadott maastrichti kritériumok logikájától. Mindez rendszerszintű problémára utal, amelyet azonban sokáig sikerült elfednie a meglévő intézményrendszernek. A jelentős eltérést mutató konvergenciatapasztalatok fényében joggal merül fel a kérdés, hogy az euroövezethez történő csatlakozás feltételeként megjelölt ún. maastrichti kritériumok és az azok fiskális feltételeinek mintájára megalkotott költségvetési szabályok miért nem voltak megfelelőek a hosszú távú gazdasági növekedés biztosításához. A kritériumok egyik hiányossága, hogy jellegükből adódóan nem mérik közvetlenül a pénzügyi és gazdasági ciklusok harmonizáltságát, a reálgazdaság konvergenciáját és a gazdasági szerkezet hasonlóságát, aminek fontosságára az elhúzódó euroövezeti válság tapasztalatai hívták fel a figyelmet (Nagy - Virág 2017).

A nehézségek az utóbbi években látványosabbá váltak, mert már az ultralaza monetáris politika sem tudta érdemben stimulálni a magánszektor beruházásait. A folyamatot felerősítette, hogy a fiskális politika az övezet egészében a kelleténél szigorúbbá vált. Mindez egyre nagyobb ellentétekhez vezet, felerősítve az "északi” és „déli” országok közötti feszültségeket. Az utóbbi hónapokban, példátlan módon, már az Európai Központi Bank (EKB) döntéshozói között is nyílt vita alakult ki a monetáris és fiskális politika közötti optimális feladatmegosztást illetően. Ennek egyik jele volt, amikor a romló konjunktúra-indikátorokra és inflációs kilátásokra reagálva az Európai Központi Bank Kormányzótanácsa 2019 szeptemberében egy átfogó monetáris lazító csomagról döntött. A lépést nem támogatta minden döntéshozó, sőt több Kormányzótanács tag a médiában élesen bírálta a meghozott intézkedéseket (Weidmann 2019; Knot 2019a). Az EKB lépésének a jelenlegi környezetben már csak mérsékelt lehet az addicionális gazdaságélénkítő hatása, emellett, előretekintve, a kilátások esetleges további romlása esetén - a jelenlegi politikai és jogi keretek között - meglehetősen korlátozott mozgástér maradhat az euroövezeti jegybank számára a monetáris kondíciók további lazítására. Mindezek fényében felmerülhet az aktívabb fiskális politika szerepe az euroövezet gazdaságának élénkítésében, ami azonban tovább élezheti az egyes tagországok gazdaságpolitikusai közötti vitát.

Az utóbbi évek monetáris politikai lépései és a mozgástér csökkenése azt jelezték, hogy a monetáris politika a jelenlegi törvényi és politikai keretek között megközelítette lehetőségeinek határait. Ezzel összhangban az elmúlt hónapokban az Európai Központi Bank döntéshozói közül egyre többen hangsúlyozták, hogy a monetáris politika korlátozottsága miatt a kellő mozgástérrel rendelkező euroövezeti országoknak a gazdasági növekedés ösztönzésére fiskális élénkítő lépéseket lenne célszerű végrehajtaniuk. Egyesek egy közös, eurozóna-szintű költségvetési keretrendszer ki- 
alakítását is kívánatosnak tartják annak érdekében, hogy hosszú távon stabilizálni tudják az övezet gazdaságát. A megszólalók között élen járt az EKB 2019. október végén leköszönt elnöke, Mario Draghi, illetve utódja, Christine Lagarde is. Tanulmányunkban megvizsgáljuk, hogy előretekintve hogyan alakulhat a gazdaságpolitikai ágak közötti koordináció az euroövezetben, mekkora mozgástér és mekkora hajlandóság lehet egy szorosabb koordináció, illetve egy aktívabb fiskális politika megvalósítására. Ezzel párhuzamosan a jelenleg érvényben lévő fiskális szabályokból fakadó problémákra is igyekszünk rávilágítani.

\section{Korlátozott mozgástér a monetáris politika számára}

A válságot követő évek markáns monetáris lazításának eredményeként az EKB döntéshozói az irányadó rátákat rendkívül alacsony szintre csökkentették, majd - más jegybankoknál később - jelentős mértékű mennyiségi lazítást hajtottak végre. Noha a jegybank 2018 decemberében leállította a nettó eszközvásárlásokat, az euroövezet lassulása és a lefelé mutató kockázatok ismételt erősödése következtében az EKB Kormányzótanácsa 2019 szeptemberében újabb átfogó monetáris lazító csomagról döntött. A jegybank laza irányultsága előretekintve tartósan fennmaradhat, kérdéses azonban, hogy egy esetleges további monetáris politikai lazítás szükségessége esetén mekkora mozgástere marad a döntéshozóknak.

Az EKB 2019 szeptemberi döntésének értelmében az irányadó betéti kamatláb -0,5 százalékra csökkent, így a mozgástér további kamatcsökkentést tekintve meglehetősen korlátozott. Ezzel párhuzamosan a Kormányzótanács szeptemberben kétsávos tartalékrendszer ${ }^{1}$ bevezetéséről és a nettó eszközvásárlások (APP) újraindításáról is döntött. A jelenlegi nyílt végú eszközvásárlási program keretében az EKB 2019. november 1-jétől havi 20 milliárd euro értékben vásárol értékpapírokat. Előretekintve azonban problémát jelenthet, hogy a kibocsátói limitek effektívvé válhatnak, gátat szabva a további vásárlásoknak. A 2015-ben indult nagy volumenű eszközvásárlások eredményeként az EKB által tartott kötvényállomány több ország, főként a magországok esetében a jegybank által meghatározott 33 százalékos kibocsátói limit közelébe emelkedett (1. ábra).

\footnotetext{
${ }^{1}$ A korábbi rendszerben a jegybanknál elhelyezett teljes szabad tartalékállomány a betéti kamaton (jelenleg -0,5 százalék) kamatozott, míg az új rendszerben a bankok a kötelező tartalékállományuk függvényében helyezhetnek el kedvezőbb kamaton (jelenleg 0 százalék) betétet az EKB-nál.
} 


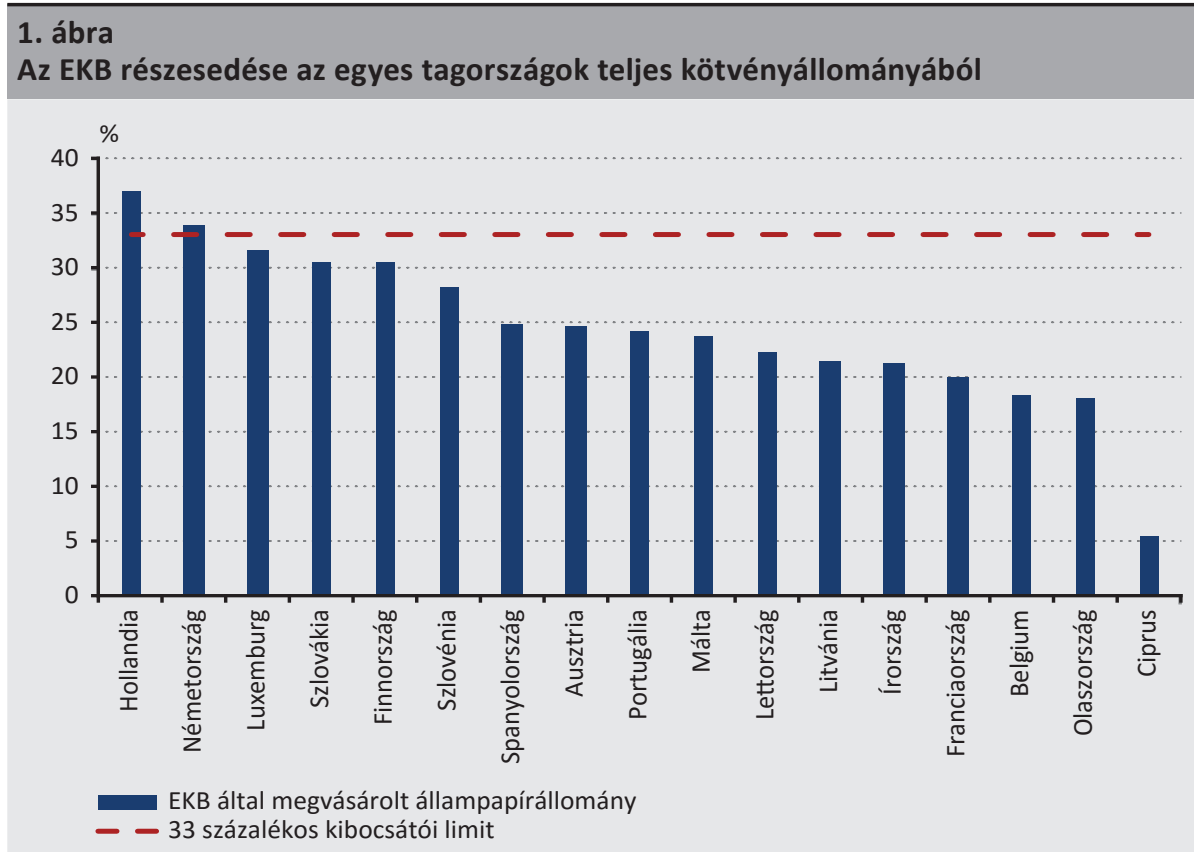

Megjegyzés: Az EKB által tartott kötvényállományok arányainak alakulásáról készített elemzői számítások viszonylag széles sávban mozognak, mert a kalkulációhoz szükségesek az egyes szuverének elérhető kötvényállományaira vonatkozó adatok is, amire azonban eltérő becslések állnak rendelkezésre. Így az egyes elemzöházak kalkulációinak eredményei között akár több százalékpontos eltérés is lehet.

Forrás: EKB és Eurostat adatok alapján számítva

Az újraindult eszközvásárlások keretében vásárolt értékpapírok összetételével kapcsolatban nem szolgált pontos útmutatással a jegybank, azonban a bejelentéskor Mario Draghi jelezte, hogy hasonló arányban fognak értékpapírokat vásárolni, mint korábban. Historikus adatok alapján a vásárlások hozzávetőleg 80 százalékát állampapírok tették ki (2. ábra). Az újraindított vásárlások első havi adatai alapján a jegybank a korábbiaknál kisebb mértékben vásárol állampapírokat, és jelentősen növelte a vállalati és fedezett kötvények részarányát, ami lehetővé teszi az EKB számára, hogy kisebb állampapír és nagyobb fedezett és vállalati kötvény vásárlása mellett hosszabb ideig futhasson az eszközvásárlási program a jelen formájában.

2019. szeptemberben elindult a korábban bejelentett TLTRO-III program is. A célzott hosszú lejáratú refinanszírozási eszközön keresztül az Európai Központi Bank olcsó, hosszú lejáratú forrást (likviditást) biztosít az euroövezet tagállamaiban múködő hitelintézetek számára. 


\section{2. ábra}

Az APP keretében vásárolt eszközök állománya és annak várható alakulása az egyes programok szerinti megosztásban

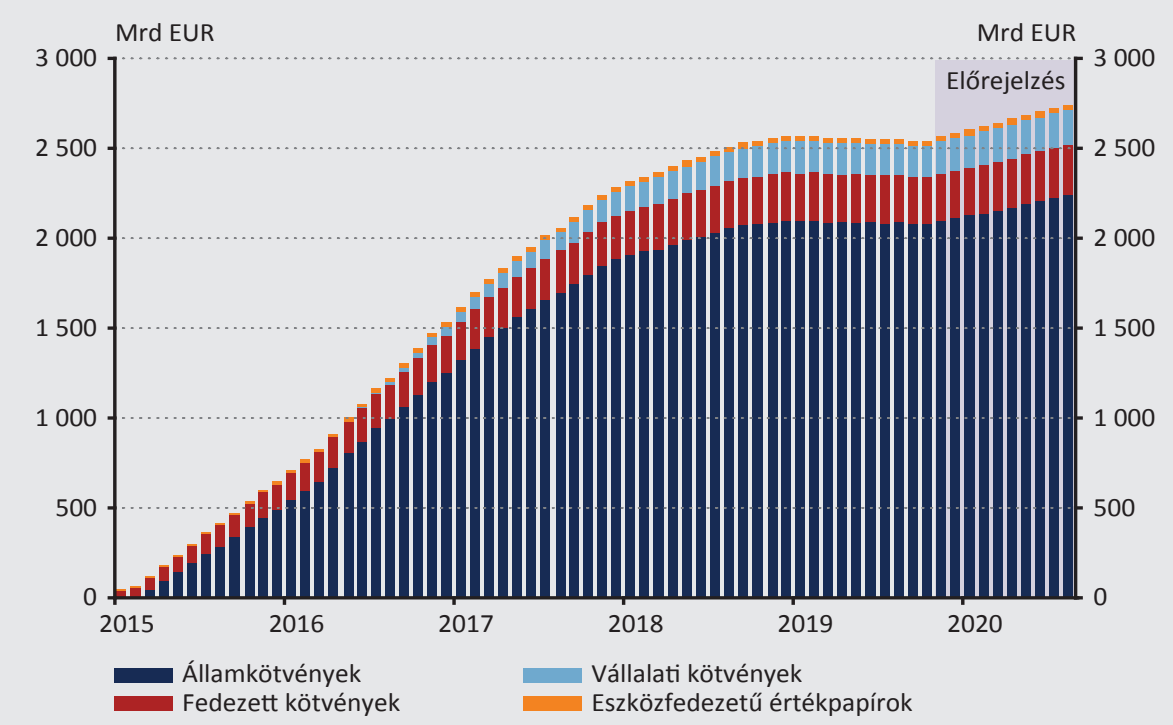

Megjegyzés: Az elörejelzés a 2019. szeptemberben bejelentett havi 20 milliárd eurós vásárlási ütemet és a korábbiaknak megfelelő értékpapir-vásárlási arányok fennmaradását feltételezi. Az újraindított vásárlások első havi adatai alapján azonban a jegybank a korábbiaknál kisebb mértékben vásárol állampapirokat, és jelentősen növelte a vállalati és fedezett kötvények részarányát.

Forrás: EKB, saját elörejelzés

\section{Romló gazdasági tendenciák az euroövezetben}

Az 1990-es években az euroövezet jelenlegi tagállamai átlagosan 2-3 százalékkal növekedtek, míg az infláció 2 százalék körül vagy afölött alakult. Ennek eredményeként a nominális GDP növekedési üteme jellemzően 4 és 6 százalék között mozgott az egyes országokban (3. ábra). Ilyen növekedési és inflációs dinamika mellett a maastrichti kritériumok és a költségvetési szabályok teljesítése nagyobb teret hagyott az egyes tagországok fiskális politikájának, hiszen magasabb nominális növekedés mellett nagyobb költségvetési hiány esetén sem feltétlenül növekszik az adósságráta. 


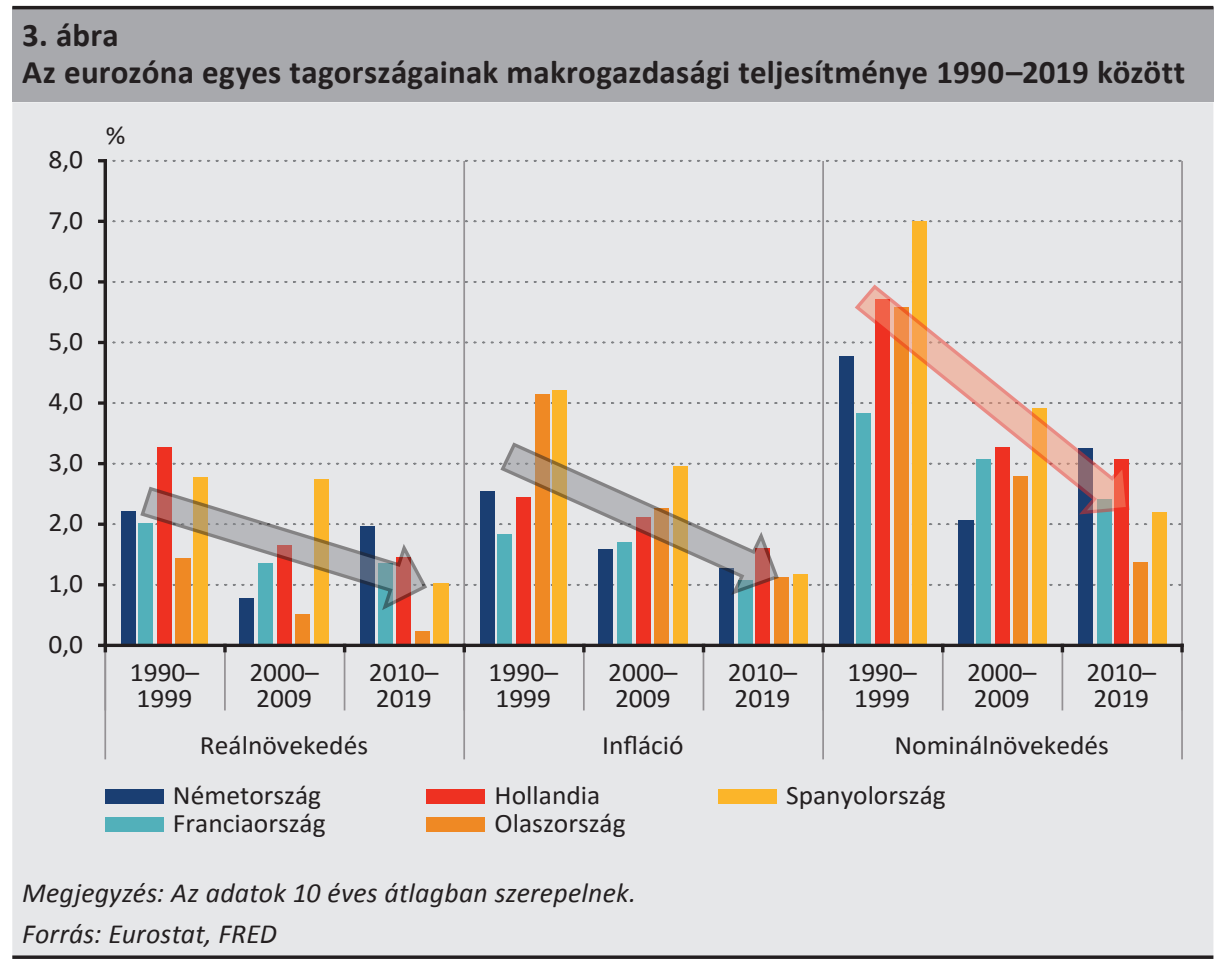

A makrogazdasági számok alapján az euroövezet gazdasága a 2000-es években is prosperált, a tagországok átlagosan 1,5-2 százalékkal növekedtek, míg az infláció a legtöbb tagországban az EKB inflációs célja közelébe csökkent. Az euroövezet kedvező teljesítménye jelentős egyensúlytalanságok felépülésével járt. A 2007/2008-as válság és az azt követő adósságválság hatására az euroövezet növekedése jelentősen lassult, és az infláció is érdemben csökkent. Az alacsonyabb infláció és reálnövekedés a korábbiaknál érdemben alacsonyabb nominális növekedési ütemet eredményezett.

Látható, hogy az 1990-es évek óta az eurozónában a makrogazdasági teljesítmény érdemben megváltozott, míg az 1992-ben életbe lépett maastrichti kritériumok a mai napig változatlanok és az euroövezetben lévő országok számára a költségvetési szabályok érvényessége miatt elvükben tovább éltek. Azon túl, hogy a válság rámutatott ezen kritériumok és szabályok hiányosságaira, a megváltozott makrogazdasági környezetet figyelembe véve célszerű lehet ezen feltételek érdemi újragondolása. A maastrichti kritériumok ugyanis egy olyan gazdasági környezetet vettek alapul, amelyben a jelenleginél érdemben magasabb reál növekedési ütem és infláció miatt a nominális növekedés is magasabb volt. A jelenlegi környezetben, amikor a nominális növekedési ütem jóval elmarad az elmúlt két évtized átlagától, az adósságráta 60 százalékos szintjének eléréséhez (de az ahhoz történő konvergenciához is) a korábbiaknál jóval szigorúbb fiskális politikára lenne szükség. Megfelelő mértékű fiskális élénkítés nélkül azonban a növe- 
kedés továbbra is visszafogott maradhat, ami az adósságráta további emelkedését, így a jelenlegi szabályrendszerben tévesen, további megszorításokat vonhat maga után.

A 4. ábrán jól látható, hogy a jelenlegi makrogazdasági környezetben az államadósság szabály nem konzisztens a deficit szabállyal, így a gyakorlatban a kettő nem alkalmazható megfelelően együtt (Pasinetti ${ }^{2}$ és Buiter ${ }^{3}$ alapján Lehmann - Palotai 2019). Az államadósság- és deficitszabályok közötti inkonzisztencia abból fakad, hogy a maastrichti kritériumokban megszabott 3 százalékos deficit csak 5 százalékos nominális GDP-növekedés mellett stabilizálja az államadósságot 60 százalékon (a fiskális szabályokról bővebben lásd a 7. lábjegyzetet). A két szabály azonban rugalmatlan, így nem veszi figyelembe az elmúlt évek makrogazdasági trendjeinek megváltozását. 1998 és 2017 között az eurozóna átlagos nominális növekedése az 5 százalék helyett már csupán 3,1 százalék volt, amely a deficitre vonatkozó előírások (3 százalék/GDP) teljesítése esetén nagyjából a GDP 100 százalékának megfelelő mértékű adósságszint mellett képes stabilizálni az államadósságot. Megfordítva, az elmúlt 10 évben tapasztalt, korábbiaknál is alacsonyabb (1,8 százalékos) növekedési trend mellett hozzávetőleg 1,1 százalékos deficit stabilizálná 60 százalékon az adósságot (Nagy et al. 2020).

\section{4. ábra}

Adósság-deficit kombinációk különböző növekedési pályák mentén

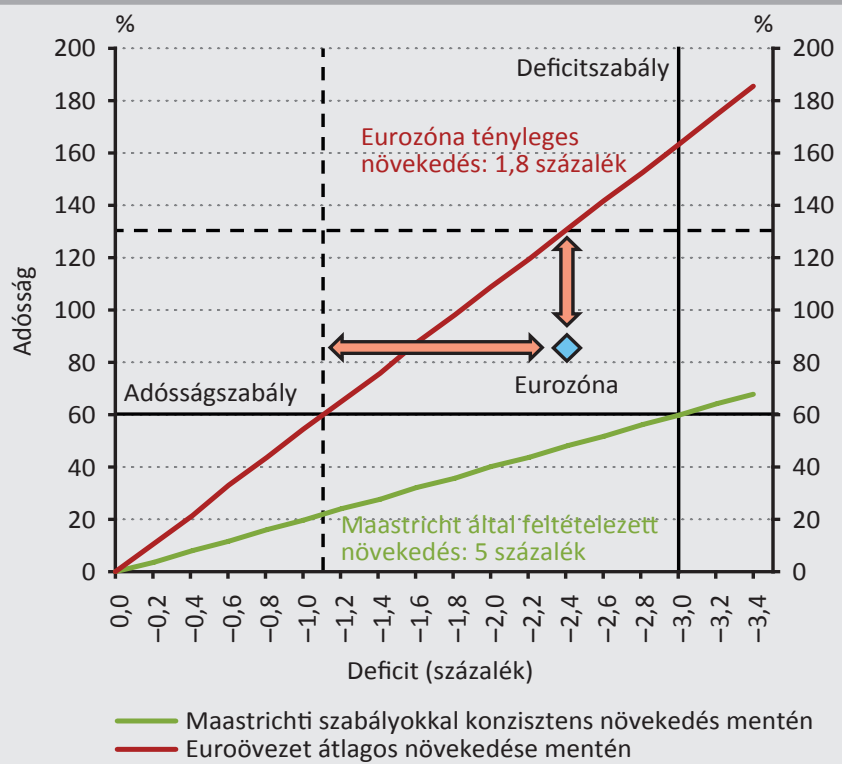

Megjegyzés: Kék rombusszal jelöltük az eurozóna aktuális deficit-és államadósság-értékeit.

Forrás: EKB, IMF

2 Pasinetti, L. (1998): The myth (or folly) of the $3 \%$ deficit/GDP parameter. Cambridge Journal of Economics, 22(1): 103-116. https://doi.org/10.1093/oxfordjournals.cje.a013701

${ }^{3}$ Buiter, W.H. (1992): Should we worry about the fiscal numerology of Maastricht? CEPR discussion papers no. 668. https://cepr.org/active/publications/discussion_papers/dp.php?dpno=668. 


\section{Fiskális politikai oldalról lenne még tér gazdaságélénkítésre}

Az euroövezetről szóló viták középpontjában - a közös fizetőeszköz létjogosultságának és alkalmasságának kérdése mellett - már a kezdetektől fogva az a dilemma állt, hogy vajon mennyire lehet sikeres egy monetáris unió közös költségvetés nélkül. A 2007/2008-as gazdasági válság felszínre hozta az euroövezet intézményrendszerének hiányosságaiból fakadó problémákat, ám hosszú távú, adekvát megoldások azóta sem születtek.

\subsection{Kezdeményezés egy közös, eurozóna-szintü fiskális kapacitás létrehozására}

Egy eurozóna-szintű közös fiskális kapacitás létrehozásáról ezidáig konkrét lépések helyett inkább csak élénk diskurzus folyt. Ezek közül is kiemelendő a 2015-ös ún. 5 elnök (Bizottság, Tanács, Parlament, Eurogroup és EKB) jelentése ${ }^{4}$, valamint 2018 júniusában Angela Merkel és Emmanuel Macron közös megállapodása, az ún. Mesebergi Nyilatkozat, amelyben a következő hétéves európai uniós költségvetési ciklus kezdetével, azaz 2021-gyel terveztek létrehozni egy közös, eurozóna-szintű költségvetést (Bagdy et al. 2020).

Az Európai Bizottság végül 2019. július 23-án hozta nyilvánosságra a Budgetary Instrument for Convergence and Competitiveness (BICC) elnevezésú dokumentumot. ${ }^{5}$ A tervezet célja egy központi forrás létrehozása az eurót használó országok számára, amely növelné a tagországok ellenállóképességét és versenyképességét, valamint strukturális reformok támogatásán keresztül segítené a gazdaságok konvergenciáját. ${ }^{6}$ Miközben ezek fontos célok a hosszú távú növekedés és kohézió szempontjából, a jelen cikkben tárgyalt optimális monetáris és fiskális politikai összhang, valamint az övezeti szintű ciklikus stabilizálás hasonlóan releváns ugyanezen szempontokból is. Az elmúlt hónapok Eurogroup-szintű vitái során azonban a hangsúly elsősorban a strukturális reformok támogatására helyeződött, nem pedig egy olyan érdemi ciklikus stabilizációs eszközre, amelynek létrehozását elsősorban Franciaország támogatná (Fleming - Khan 2019). Az eurozóna-szintű közös költségvetés pontos méretéről egyelőre nem született megállapodás, azonban valószínúnek tűnik, hogy Emmanuel Macron ambiciózus tervei ellenére (amelyek az eurozóna GDP-jének több százalékáról szóltak) egy eurozónaszinten nem jelentős összegről, 7 év alatt mindössze 15-20 milliárd euróról lehet szó (Bagdy et al. 2020).

A javaslat szerint a közös költségvetés finanszírozása a többéves EU-s költségvetési keretből történne, amit az egyes tagállamok kiegészíthetnének. A pontos összeg ezáltal a teljes EU-s költségvetési tárgyalások részét képezi. A diskurzus további

${ }^{4}$ Five Presidents' Report. Plan for strengthening Europe's Economic and Monetary Union as of 1 July 2015. https://europa.eu/rapid/press-release_IP-15-5240_en.htm. Letöltés ideje: 2019. december 9.

${ }^{5}$ Budgetary Instrument for Convergence and Competitiveness. Commission proposes a governance framework for the Budgetary Instrument for Convergence and Competitiveness. https://ec.europa.eu/commission/ presscorner/detail/en/ip_19_4372. Letöltés ideje: 2019. december 9.

${ }^{6}$ Bizonyos esetekben megfelēő strukturális és versenyképességi reformok, illetve a költségvetés szerkezeti átalakítására irányuló gazdaságpolitikai lépések a költségvetési hiány csökkenése mellett is támogathatják a növekedést. 
kérdéses eleme, hogy legyenek-e önálló forrásai is a közös költségvetésnek, azonban jelen állás szerint ez nem tûnik valószínűnek. A tárgyalások során a nettó befizetők, elsősorban az észak-európai országok nyomására Mario Centeno, az Eurogroup elnöke kijelentette, hogy várhatóan az eurozóna-tagállamok befizetéseik legalább 70 százalékát vissza fogják kapni (Bagdy et al. 2020). Ez megkérdőjelezné a közös költségvetés létrehozásának értelmét, hiszen így a fiskális kapacitás meghatározó hányada nem kerülne újraelosztásra, amelynek következtében érdemi strukturális reformok megvalósítása nem tűnik reális forgatókönyvnek.

\subsection{Az egyes tagállamok által benyújtott jövő évi költségvetési javaslatok}

Az EKB 2019. szeptemberi átfogó lazítócsomagjának bejelentésekor a sajtótájékoztatón Mario Draghi hangsúlyozta, hogy a monetáris kondíciók ismételt lazítása fiskális expanzió nélkül nem fogja tudni érdemben stimulálni az euroövezet gazdaságát. Az EKB válságot követő lazító lépéseinek eredményeként az egyes országok államadósság után fizetett kamatkiadásai jelentősen csökkentek, így a tagállamok a korábbiaknál kedvezőbb finanszírozási költségek mellett tudnának lazítani fiskális politikájukon. Az Eurostat adatai szerint euroövezeti szinten az állami kamatkiadások 2012-ben még a GDP 3,0 százalékát tették ki, míg 2019-re ez az arány 1,8 százalékra csökkent, és az EKB szeptemberi lazítása a kamatkiadások további csökkenésének irányába mutat. Ennek ellenére azonban a tagországok jövő évre vonatkozó költségvetési tervezete alapján nem várható érdemi fiskális élénkítés (5. ábra), ami részben azzal is magyarázható, hogy egyes tagországokban az államadósság jelenleg magasabb, mint amekkora a válság előtt volt.

\section{5. ábra \\ A 2019-es és 2020-as költségvetési egyenlegre vonatkozó tervek alakulása az egyes euroövezeti tagországokban}

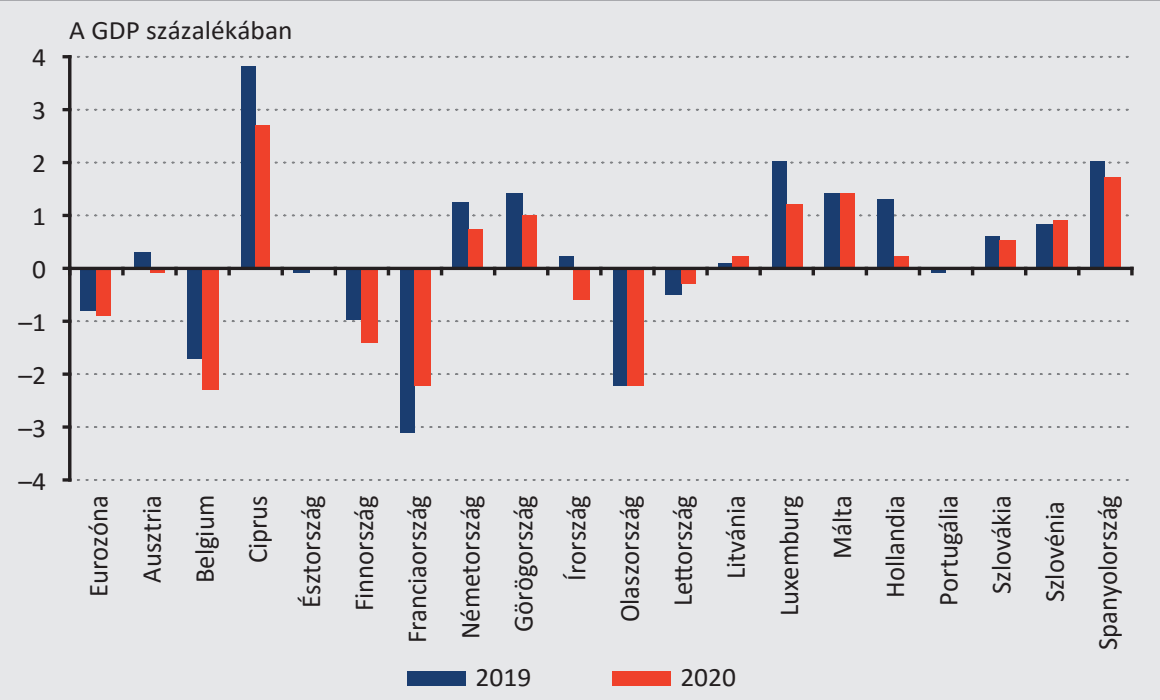

Forrás: Európai Bizottság, HSBC (2019) alapján 
A fiskális politika irányultságát jobban megragadja a költségvetés strukturális elsődleges egyenlege, amely a teljes egyenleggel szemben nem tartalmazza a kamatkiadásokat, illetve az üzleti ciklus hatásait, így pontosabb képet fest az állami költekezés alakulásáról. Azonban a strukturális elsődleges egyenleg alapján is az látható, hogy a 2019-es évhez viszonyítva csak enyhe lazítás várható, a teljes euroövezet szintjén a GDP 0,4 százalékának megfelelő addicionális fiskális impulzusra lehet számítani 2020-ban (6. ábra). Az elmúlt időszakban főleg azokat az országokat érte kritika fiskális politikájukat illetően, amelyek évek óta jelentős többletet halmoznak fel, és jelen helyzetben sem hajlanak fiskális kiengedésre.

Hollandia részéről mutatkozik némi nyitottság, a holland kormányzat egy alap létrehozását tervezi, amely infrastrukturális beruházásokat és kutatást hivatott majd támogatni. Németország vonatkozásában ugyanakkor nem várható jelentős változás, a német pénzügyminiszter, Olaf Scholz szerint a német gazdaság pénzügyi helyzete szilárd, és csak jelentős gazdasági visszaesés esetén fog a kormányzat érdemi fiskális élénkítés mellett dönteni. Az elmúlt időszakban ugyan a német kormányzat bejelentett egy 54 milliárd euro keretösszegű klímavédelmi alapot, ugyanakkor az alapot adóemelésből és szén-dioxid kvóták eladásából tervezik fedezni, így nem várható érdemi változás a fiskális politika irányultságában. Azok az országok pedig, amelyek jelenleg is deficittel terveznek a jövő évre, vagy adósságrátájuk a kívánt szint felett van, mint például Olaszország, Spanyolország vagy Franciaország, a maastrichti adósságszabályok miatt korlátozva vannak a fiskális lazítás terén.

\section{6. ábra \\ A strukturális elsődleges egyenleg várható változása 2019 és 2020 között az egyes euroövezeti tagországokban}

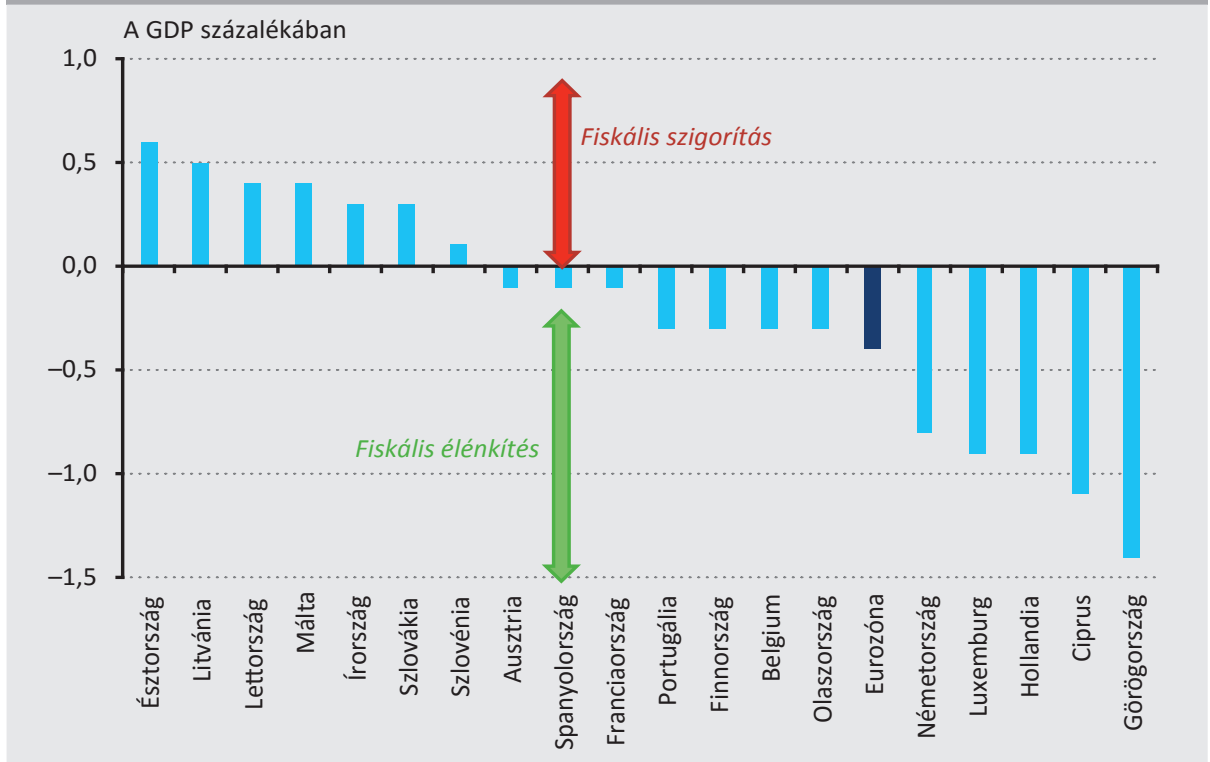

Forrás: HSBC (2019) alapján 


\subsection{Fiskális politikai mozgástér az euroövezetben}

Az elmúlt időszakban jelentősen megnőtt az igény a fiskális és monetáris politika összehangolására. Az Európai Központi Bank eszközvásárlási programjának újraindításával és a historikusan alacsony betéti kamatláb elérésével egyre gyakrabban merül fel a kérdés mind a piaci szereplők, mind a gazdaságpolitikai döntéshozók részéről, hogy meddig képes még élénkíteni a monetáris politika az eurozóna gazdaságát. Több prominens gazdaságpolitikus és döntéshozó is megfogalmazta azon véleményét, miszerint a fiskális politikának nagyobb szerepet kellene vállalnia a gazdaság élénkítésében, illetve nagyobb mértékű koordinációra lenne szükség a két gazdaságpolitikai ág között.

A koordinált fiskális expanzió lehetőségét azonban a maastrichti kritériumokon alapuló és az azokat pontosító fiskális szabályok is korlátozhatják. Miközben a maastrichti konvergenciakritériumok számszerűen olyan értékeket határoznak meg, amelyeket csak átmenetileg és kivételes esetekben haladhatnak meg a deficit- és adósságráták, a pontosítások a normál időkre is számszerűsíthető és szankcionálható, számszerű értékeket határoznak meg. ${ }^{7}$ Ezek az idők során egyre összetettebbé váló szabályok továbbra is függetlenek az aggregált kereslet alakulásától és a gazdasági szektorok nettó pozíciójától, így nincsenek tekintettel az optimális gazdaságpolitikai összhang követelményeire, sem nemzetállami, még kevésbé euroövezeti szinten. Több országspecifikus hatás eredőjeként magyarázható, hogy miért nem folytatnak az eurozóna országai összehangolt fiskális politikát, amelynek következtében várhatóan magasabb növekedési és célközeli inflációs pályára állna a monetáris unió országainak gazdasága. Az egyik legfontosabb tényező, hogy eltérő államadósságszintről kellene elindítani az expanziót, aminek azonban gátat szab a hatályos maastrichti szabályozás, mivel a déli országok adósságának szintje jelenleg érdemben meghaladja a 60 százalékos korlátot (7. ábra).

\footnotetext{
${ }^{7}$ A pontosítások lényege, hogy a fiskális politika a gazdaság ciklikus mozgására nézve legyen semleges abban az értelemben, hogy ciklusátlagban a deficit legyen közel a zéróhoz. A szabályok megengedik, hogy gyenge ciklikus helyzetben a költségvetési deficit stabilizáljon, lehetőleg csak az úgynevezett automatikus stabilizátorok révén ( $\mathrm{pl}$. munkanélküli segély), illetve trendet meghaladó növekedés esetén hűtse a gazdaságot költségvetési többlettel (pl. az automatikusan növekvő adóbevételek) és minimális „diszkrecionális" intézkedéssel. A semleges ciklikus irányultság mellett a szabályok figyelembe veszik az olyan várható jövőbeni kiadásnövekedéseket, mint az idősödés miatti növekvő kifizetések, és előtakarékosságot várnak el fiskális többlet formájában. A komplex szabályok tehát a gazdasági növekedést teljesen függetlennek tekintik, valójában függetleníteni kívánják a fiskális politikától, és az előtakarékosságot a háztartások analógiájára javasolják. Amint később jelezzük, ezen megfontolásokat nem tartjuk megfelelőnek. A szabályok érvényesítése aszimmetrikus, mert a pozitiv eltéréseket (túl szigorú fiskális politikákat) nem tekinti hibának, és ennek megfelelően nem is szankcionálja. Az övezet egésze szintjén így nem számon kérhető, hogy a szabályok szerint mozgástérrel rendelkező országok lazítsanak a fiskális politikáikon annak érdekében, hogy pótolják az ebben korlátozott országok hiányzó mozgásterét.
} 


\section{7. ábra}

A GDP-arányos államadósság szintjének várható alakulása az eurozóna országaiban 2019 végén

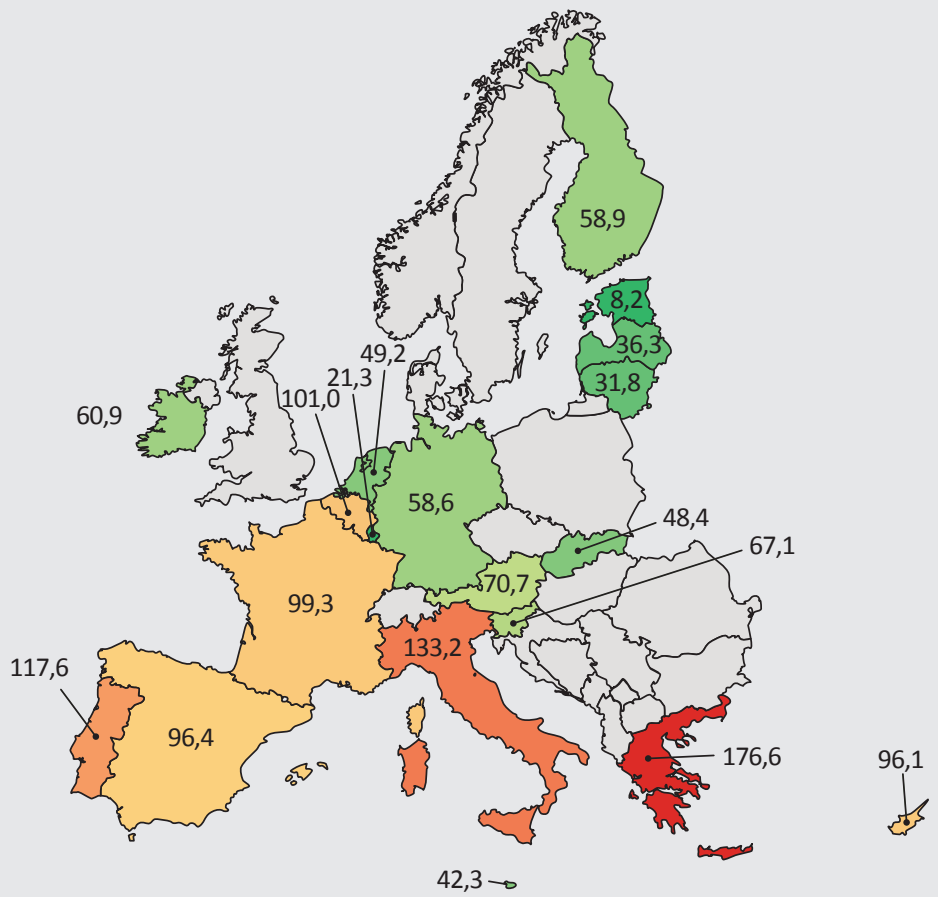

Forrás: IMF WEO adatbázis

A GDP-arányos államadósságszintet vizsgálva megállapítható, hogy továbbra is jelentős az észak-dél törés az eurozóna országai között. Mivel az adósság-konvergencia nem valósult meg az elmúlt évtizedben a megszorító politikák mellett sem, ezért jelen helyzetben a dél-európai országok, amelyeknek szüksége lenne a lazább fiskális politika adta gazdaságélénkítésre, nem rendelkeznek kellő mozgástérrel, míg az északi országok, amelyek képesek lennének élénkíteni, nem kívánnak élni a lehetőséggel.

Az államadósság szabta szűkebb mozgástér részben a fennálló kamatteher és a viszszafogott inflációs folyamatok következménye. Az eurozóna-országokra jellemző mérsékelt adósságdinamika azt mutatja, hogy a pénzügyi és a szuverén válságot követően nem sikerült jelentős mértékben növelni a fiskális politika mozgásterét. Annak ellenére, hogy az Európai Központi Bank tartósan alacsony kamatszintet biztosított, a korábban felépülő adósság kamatterhe jelentős nyomás alá helyezte a zóna országainak költségvetéseit (8. ábra). További nehézséget jelent, hogy a különböző nemkonvencionális eszközök bevezetése mellett sem sikerült olyan élénkítést elérni, amely mellett az adósságráta gyorsabban mérséklődött volna. 


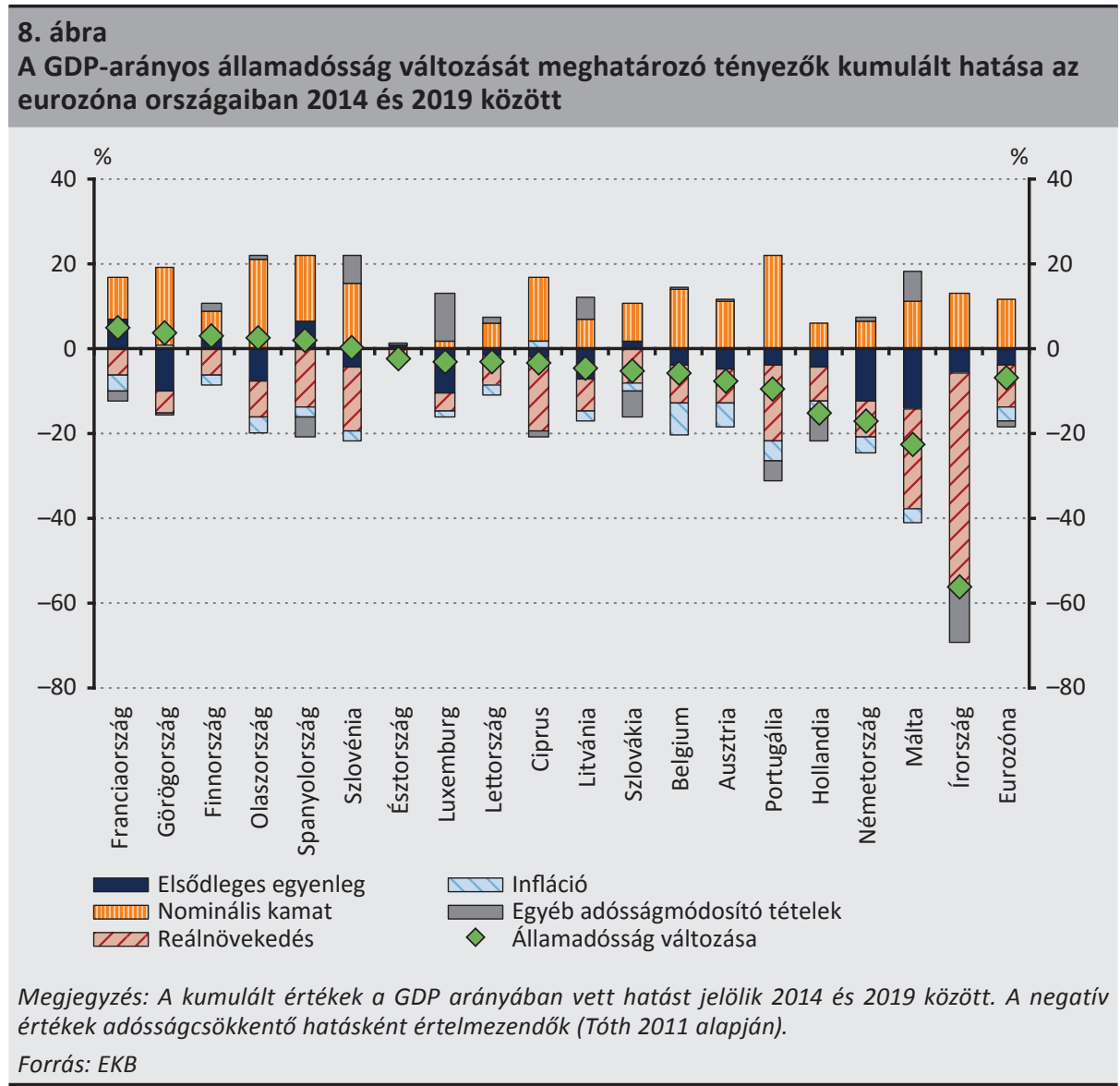

A 8. ábra alapján megállapítható, hogy legnagyobb mértékben a reálnövekedés hatott az államadósság mérséklődésének irányába, amely több országban is képes volt ellensúlyozni a magas kamatteher ellenkező irányú hatását. Mindezek mellett a költségvetési többlet a legtöbb tagország esetében marginális mértékben csökkentette az adósságrátát, miközben mérsékelhette a tagállamok potenciális és tényleges növekedését egyaránt. A növekedés ezen típusú „kiszorítása” jelentős negatív hatást gyakorolt Görögországra és Olaszországra, amely országokban átlag alatti növekedés és többletes elsődleges egyenleg mellett növekedett az államadósság.

A válság előtti (Brüsszel-Frankfurt-Washington) konszenzus szerint a diszkrecionális fiskális politika általában nem hasznos a ciklikus stabilizálás céljaira, mert lassú a döntési és implementációs mechanizmusa, és gyakran politikailag népszerútlen az élénkítés visszavétele a szükséges időn túl. Egyébként pedig azt feltételezték, hogy a ciklikus lassulás nem okoz tartós visszaesést a GDP pályájában. A lassú kibontakozás és az USA-EU-összehasonlítás azonban megváltoztatta a többségi szakmai közvéleményt. Az újabb fiskálismultiplikátor-becslések hangsúlyozzák a mért eredmények 
állapotfüggőségét: míg a válság előtt körülbelül 0,5-es multiplikátorral számoltak (Európai Bizottság, IMF, OECD), addig a válság után gyakran az 1-et akár jelentősen meghaladó értékek a tipikusak (Blanchard - Leigh 2013). A fiskális multiplikátor azt mutatja meg, hogy a költségvetési kiadások növelése milyen mértékben növeli a GDP-t. Egynél nagyobb érték esetén a GDP a kiadásokat meghaladó mértékben növekszik, vagyis a költekezés hatásának kibontakozását követően az adósságráta csökkenhet, a kezdeti adósságszinttől függően (egységnyi multiplikátor esetén változatlan marad). Ha egynél kisebb a multiplikátor, akkor a deficit növekedését (vagy a többlet csökkenését) később egyéb kiadáscsökkentéssel vagy adóemeléssel lehet szükséges társítani az adósságráta növekedésének megakadályozásához.

Ennek ellenére számos európai gazdaságpolitikus vonakodik a kezdeti deficitnöveléssel vagy a meglévő többlet csökkenésével járó költekezést választani, inkább szigorú fiskális politikát alkalmazva kívánják csökkenteni az adósságrátát. Ez azonban szintén hátrányokkal járhat, ha valóban egységnyi vagy nagyobb a multiplikátor, mert így az adósságráta még nőhet is. Egy másik megfontolás az lehet, hogy még ha egységnyi vagy nagyobb is a multiplikátor, a piacok rosszul fogadnák a deficit növelését és magasabb kamatokat várnának el, vagy akár szabadulni is próbálnának az állampapíroktól, megnehezítve az adósság finanszírozását. Ez a megfontolás az állampapírkamatok és az adósság fenntarthatóságának problémáját veti fel.

De Grauwe és Ji (2019) kiszámították, hogy az eurozóna országainak mekkora mozgástere van a deficit növelésére a kialakult kamatkörnyezetben. A szokásos számítási eljárást alkalmazták, vagyis a kamatok és a növekedési ütem különbsége alapján meghatározták a deficit növelésének azon mértékét, amely mellett az adósságráta változatlan maradna. Azt találták, hogy 2018-ban az euroövezetben Görögország és Olaszország kivételével minden országban magasabb a növekedés üteme az állampapírkamatoknál. Ezek alapján az egyes országok költségvetési egyenlege az adósságráta változatlansága mellett jelentősen, akár mínusz három-négy százalékkal is változhatna a kiinduló, gyakran pozitív elsődleges egyenleghez képest, azaz ekkora fiskális élénkítésre lenne mód (1. táblázat). Ez a mozgástér különösen fontos egy olyan időszakban, amikor a növekedési kilátások romlanak. 


\begin{tabular}{|c|c|c|c|c|c|}
\hline \multicolumn{6}{|c|}{$\begin{array}{l}\text { 1. táblázat } \\
\text { Fiskális mozgástér egyes euroövezeti tagállamokban, az államadósság-ráta } \\
\text { változatlansága mellett }\end{array}$} \\
\hline Ország (2019) & Adósság / GDP & $r-g$ & $\begin{array}{c}(\mathrm{r}-\mathrm{g}) /(1+\mathrm{g}) * \\
\text { Adósság }\end{array}$ & $\begin{array}{c}\text { Elsődleges } \\
\text { egyenleg }\end{array}$ & $\begin{array}{l}\text { Fiskális } \\
\text { stimulus }\end{array}$ \\
\hline Ausztria & 69,7 & $-3,3 \%$ & $-2,3 \%$ & $1,8 \%$ & $4,1 \%$ \\
\hline Belgium & 101,3 & $-2,4 \%$ & $-2,5 \%$ & $0,8 \%$ & $3,3 \%$ \\
\hline Finnország & 58,3 & $-2,9 \%$ & $-1,7 \%$ & $0,5 \%$ & $2,2 \%$ \\
\hline Franciaország & 99 & $-1,6 \%$ & $-1,6 \%$ & $-1,5 \%$ & $0,1 \%$ \\
\hline Görögország & 174,9 & $4,8 \%$ & $8,4 \%$ & $4,0 \%$ & $-4,3 \%$ \\
\hline Hollandia & 49,1 & $-3,4 \%$ & $-1,7 \%$ & $2,2 \%$ & $3,9 \%$ \\
\hline Írország & 61,3 & $-6,4 \%$ & $-3,9 \%$ & $1,4 \%$ & $5,4 \%$ \\
\hline Németország & 58,4 & $-3,1 \%$ & $-1,8 \%$ & $1,8 \%$ & $3,6 \%$ \\
\hline Olaszország & 133,7 & $0,0 \%$ & $0,0 \%$ & $1,2 \%$ & $1,2 \%$ \\
\hline Portugália & 119,5 & $-1,2 \%$ & $-1,4 \%$ & $2,9 \%$ & $4,3 \%$ \\
\hline Spanyolország & 96,3 & $-2,3 \%$ & $-2,2 \%$ & $0,0 \%$ & $2,2 \%$ \\
\hline
\end{tabular}

\subsection{Fiskális politika szektorális elemzési keretben}

A fiskális politika aktívabb szerepe a fentiekben mutatott, szokásos elemzési kereteken túl még határozottabban igazolható egy olyan elemzési keretben, amely figyelembe veszi a főbb gazdasági szektorok pénzügyi pozícióját, azok összefüggését. ${ }^{8} \mathrm{Az}$ alapgondolat egyszerü: az egyes gazdasági szektorok pozíciói szorosan összefüggenek, és szükségképpen egymással összeegyeztethetőnek kell lenniük. Ugyanúgy, ahogy egy elemi piaci tranzakcióban egy eladónak mindig találnia kell egy vevőt, az egyes gazdasági szektorok szintjén is igaz, hogy nem lehet többletes egy szektor anélkül, hogy egy másik szektor deficites ne lenne, ${ }^{9}$ illetve egy gazdasági szektor zéró pozíciója csak akkor lehetséges, ha a többi szektor együttesen szintén zéró pozíciót mutat. A legegyszerúbb esetben három szektort különböztetünk meg: a nem-banki magánszektort (azaz összevont háztartási-vállalati szektor), a kormányzatot és a külföldet ${ }^{10}$. A magánszektor makroszinten tipikusan nettó megtakarító, mert kevesebbet ruház be a saját megtakarításainál $(S>I)$. A kormányzati szektor adók és kiadások egyenlege $(T-G)$ és a külföldi szektorok export-import egyenlege

\footnotetext{
${ }^{8}$ A szektorális összefüggésekkel kapcsolatos téma összefoglalása Balázs et al. (2020) tanulmányában is megtalálható. Jelen szakaszban az ott megjelenítettek kerültek kiegészítésre, bővebb kifejtésre.

${ }^{9}$ Ezt a szükségszerű, számviteli azonosság erejével ható követelményt gyakran szem elől tévesztik a modern makrogazdasági elméletekben, amelyekben az egyéni szereplő döntéseire vezetik vissza a makroszintű kimeneteleket. Ezen nem sokat változtat a valóságos szereplői magatartásokat realisztikusabban leírni szándékozó viselkedési modellek megjelenése. Ugyanakkor az újabban népszerű, ágens alapú modellek ezt a hiányosságot kívánják orvosolni. Kregel és Parenteau azonban a Godley által régóta képviselt stock-flow konzisztens modellekre épít. E két irányzat eredményeit kapcsolja össze egy, a Bank of England-nél megjelent tanulmány (Barwell - Burrows 2011). Lásd még Caiani et al. (2016).

${ }^{10}$ Kregel (2015), illetve Parenteau (2010), valamint Godley - Lavoie (2007).
} 
$(X-M)$ változékonyabb, de együttes egyenlegük szükségképpen a magánszektor egyenlegével egyezik meg: $(S-I)=(G-T)+(X-M)$. Maradva a tipikus esetnél, a magánszektor csak akkor lehet nettó megtakarító, ha vagy a kormányzat, vagy a külföld hajlandó eladósodni vele szemben (9. ábra). Ha a külföld erre nem hajlandó, akkor csak a kormányzat marad a maga deficitjével a „végső adós” (Balázs et al. 2020).

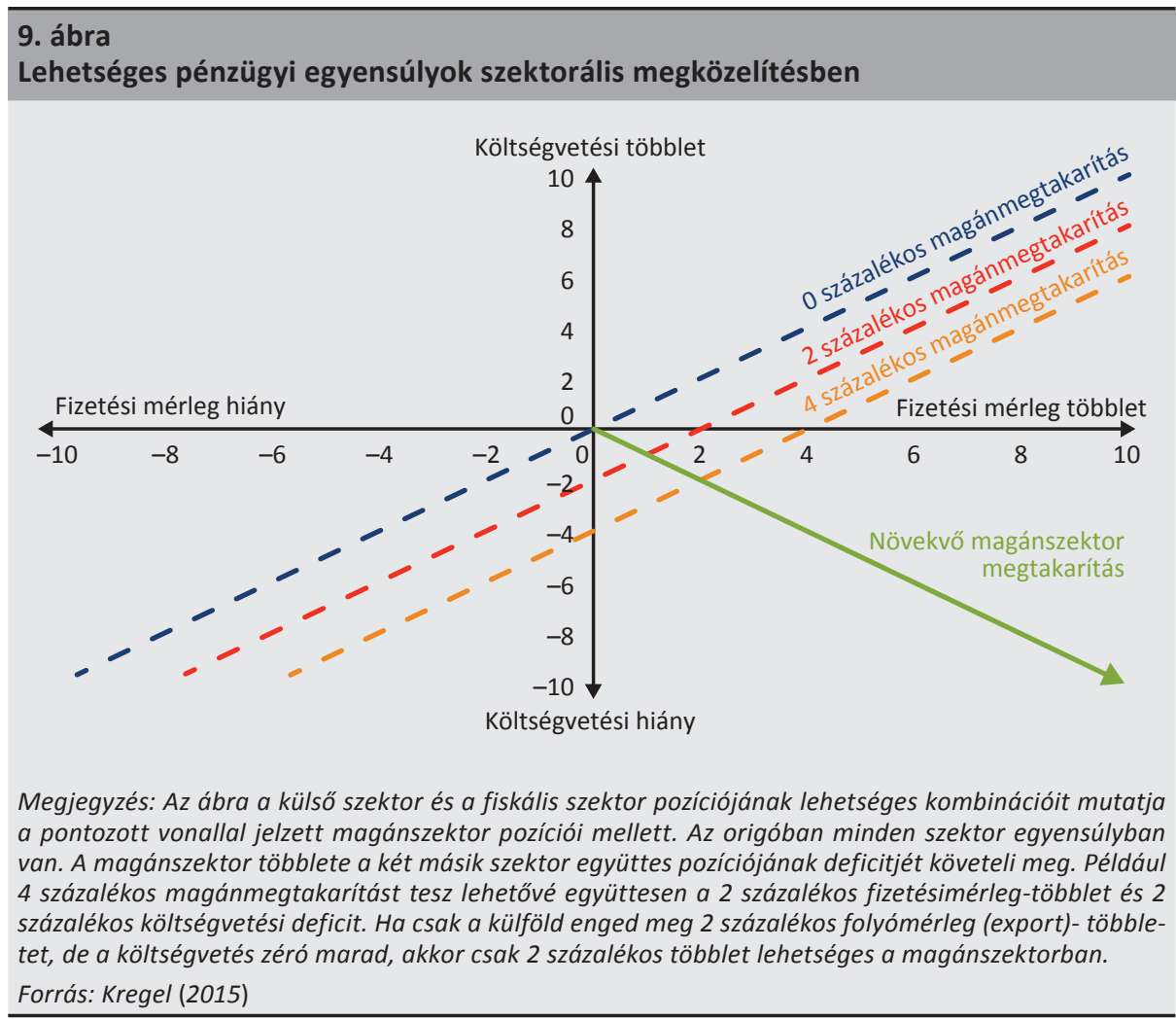

A fő probléma az euroövezeti fiskális szabályokkal, hogy nem veszik figyelembe a szektorális egyensúlyok összefüggését. A fiskális szabályok hasonlóak minden résztvevő országra. A pénzügyi válság miatt megnövekedett adósságállományok és költségvetési deficitek miatt kiigazítást követelnek meg szinte minden országtól, miközben a magánszektorok is, a mérlegeik kiigazítása miatt, még inkább nettó megtakarítók. Eltekintve a válság utáni mérlegkiigazítástól, általában is igaz, hogy a fiskális szabályok normál időkben vagy ciklusátlagban semleges irányultságot írnak elő: a deficit nem lehet nagyobb három százaléknál és a középtávú fiskális cél átlagban zéró deficitet követel meg (illetve országonként eltérő mértékben némi többletet az öregedés ütemével). Azaz, amennyiben igaz, hogy a magánszektor tipikusan nettó megtakarító az euroövezetben, akkor a gazdaságnak nincs belső 
dinamizmusa, saját növekedési modellje. Az övezet így továbbra is exportorientált, úgynevezett „kis, nyitott gazdaságok”-ra jellemző stratégiát követ.

Emiatt a növekedéshez szükséges aggregált kereslet nem érkezhet máshonnan, mint a külföldi szektortól. Egy növekvő világgazdaságban, ahol van olyan régió, amelyik hajlandó eladósodni, ez az úgynevezett „exportvezérelt” növekedési modell múködhet, és működött is a válság előtt. Az USA volt a végső kereslet biztosítója a világgazdaságban, részben a költségvetési hiány, részben a magánszektor eladósodása réven. ${ }^{11} \mathrm{~A}$ válság nyomán azonban a világgazdaságban szintén gyenge a növekedés, és a külföldi szektorok is a válság előtti adósságaik leépítésére törekednek. Így kérdés, hogy lehetséges-e kielégítő mértékű növekedés az euroövezetben. A nettó export további növelése olyan mértékű bérnövekedés- és beruházás-visszafogást igényel, ami a belföldi növekedést még inkább visszafogja. Ebben az esetben a fiskális deficit növekedése híján az EU-szabályok által megengedett intézkedések éppen a növekedést fogják vissza (Balázs et al. 2020). A Keynes által a megtakarítások paradoxonának nevezett jelenség stagnálást és az övezet instabilitását idézheti elő. ${ }^{12}$

Ennek a stagnálásra hajló gazdasági kormányzásnak a költségei nagyobbak lehetnek a korábban feltételezettnél, amikor a gazdasági növekedést önfenntartó folyamatnak gondolták, ami nem igényel szisztematikus gazdaságpolitikai ösztönzést. A kínálati oldalt ugyanis exogénnek, az aggregált kereslettől függetlennek tekintették. Újabb kutatások a népesség növekedésén és a technológiai fejlődésen kívül más, a kormányzat által befolyásolható tényezőket is figyelembe vettek (pl. oktatás, humán tőke, társadalmi tőke, kutatás-fejlesztés), de jellemzően még ezek az elemek sem igényelték az aggregált kereslet menedzselését. A növekedési modellekben így az aggregált keresletnek nem maradt szerepe, még az endogén modellekben sem.

A válság tapasztalatai alapján azonban érik az a felismerés, ami egy korábbi, főleg Keynes által inspirált közgazdász generáció számára ismerős volt: az aggregált kereslet menedzselése nélkül a gazdaság hajlamos a stagnálásra. Ebben az esetben stimulusra, és ezzel a teljes foglalkoztatási cél előmozdítására van szükség a kielégítő növekedési ütem eléréséhez. ${ }^{13}$ Ellenkező esetben a lassú növekedési ütem állandósulhat, amelynek során a beruházási aktivitás visszafogott marad, és a munkanélküliség magasan stabilizálódik. A kínálati oldal így endogén módon, a gyenge aggregált keresletre válaszul tartósan sérül, amit a szakirodalomban hiszterézisnek

${ }^{11}$ Bibow és Terzi (2007) erősebb nyelvezetet használ: ezt a növekedési modellt potyautazásnak nevezik.

12 Megjegyzendő, hogy az exportvezérelt gazdasági modell nagyobb régiók számára, és különösen a világgazdaság egésze számára nem múködhet. Kregel (2010) kimutatja, hogy az exportvezérelt országok felvevőpiacaiként szolgáló nettó deficites partnerországokban előbb-utóbb Ponzi-játékhoz hasonló helyzetet eredményez: a külföldi devizában fennálló adósságszolgálatot (kamatokat) és folyó külkereskedelmi deficitet csak devizahitellel tudják finanszírozni, ami a Minsky által spekulatív pozíciónak nevezett Ponzi-rezsimnek felel meg.

${ }^{13}$ Természetesen nem cél a költségvetési hiány folyamatos növelése, ezzel szemben a költségvetésnek a reálgazdaság pozíciója, a külső kereslet, az egyes szektorok pozíciói, valamint a többi gazdaságpolitikai eszköz lehetőségeinek figyelembevételével célszerű reagálnia. 
neveznek (bővebben Id. Lehmann et al. 2017). Ha ezt a mechanizmust a válság előtti konszenzus szellemében figyelmen kívül hagyjuk, és az aggregált kereslettől független adottságnak tekintjük, akkor ezt azonosítva a gazdaság maximális növekedési képességével (potenciális kibocsátás) a gazdaságpolitika a gyorsabb növekedést látva és az inflációtól tartva fékezni fogja a gazdaságot. Így, ami kezdetben csak az elégtelen kereslet miatti átmeneti lassulás volt, a valóságban, a gazdaságpolitikai lépések következtében (fiskális visszafogás, jegybanki kamatpolitika) tartóssá válik. ${ }^{14}$ Az elmúlt évek tapasztalatai rávilágítottak arra, hogy a teljes kapacitáskihasználtság megállapítására önmagában a munkanélküliségi ráta vizsgálata nem elegendő. A munkanélküliségi ráta ugyanis a korábban egyensúlyinak tekintett szint alá is csökkenhet, ha közben a munkanélküliség természetes rátája is mérséklődik. Ebben az esetben ez nem feltétlenül jelenti azt, hogy a gazdaság elérte a teljes kapacitáskihasználtságot. Erre Jerome Powell (2018), a Fed jelenlegi elnöke is rámutatott beszédében, amelyben kiemelte, hogy a munkanélküliség természetes rátájának becslése meglehetősen bizonytalan, ahogy arra több tanulmány is rámutat (például Orphanides - Williams 2005).

A potenciális kibocsátás endogenitását empirikusan azért nem könnyú igazolni, mert a gazdasági szereplők reakciójának rá gyakorolt hatása tükröződik az adatokban. ${ }^{15}$ A válság előtt a gazdaságpolitikusok dilemmája az volt, hogy ha akár átmenetileg is magasabban alakul az infláció a célnál, akkor közvetlen veszélyként idéződött fel az inflációs várakozások megemelkedése és a túlzottan magas infláció veszélye, amit el akartak kerülni. Ezt erősítette, hogy az esetleges gazdaságpolitikai hiba - a túl korai szigorítás - költségmentesnek tűnt, mert nem gondolták, hogy a potenciális kibocsátás tartósan sérülhetne. A válság nyomán azonban ez az értékelés megfordult: miközben az infláció a legtöbb országban az érdemi jegybanki élénkítő programok és a historikus mélyponton lévő munkanélküliség mellett sem tér vissza a célhoz, a lassú növekedés tartósan alacsony potenciális növekedési ütemet okoz.

Az egyes szektorok egyenlegeit vizsgálva elmondható, hogy a magánszektor egésze és önmagában a nem pénzügyi vállalatok euroövezeti szinten gyakorlatilag folyamatosan megtakarítói pozícióban vannak (10. ábra). A válságot követően a fiskális politika ugyan átmenetileg nagyobb deficit mellett múködött, mára azonban övezeti szinten szinte teljesen egyensúlyba került. A magánszektor megtakarításait így

\footnotetext{
${ }^{14}$ Azt a legtöbb elemző elfogadja, hogy az egyidejű potenciális kibocsátás becslései, hasonlóan a természetes munkanélküliségi ráta becsléseihez, bizonytalanok, és tipikusan követik a tényleges növekedést és munkanélküliséget. Emiatt nagyon gyakoriak az utólagos revíziók, és az újabb adatok alapján a "múlt” folyamatosan változik. Az ilyen becsléseken alapuló gazdaságpolitikák irányultsága hasonló módon, utólag más megvilágítást kaphat: korábban élénkítőnek tekintett gazdaságpolitika semlegesnek vagy akár restriktívnek mutatkozik, és fordítva.

${ }^{15}$ Klasszikus hivatkozás Okun (1973) nagynyomású gazdaságpolitikát javasló cikke a stagnálás és a növekvő munkanélküliség visszafordítására, amelyet a pénzügyi válságot követően Ball (2015) idézett fel. Lásd még Blanchard - Summers (1986). Európában Kaldor nyomán a keynesi, post-keynesi irodalomban mindig jelen volt a gondolat, Id. Ledesma - Thirlwall (2000), Fatas - Summers (2018), Heimberger - Kapeller (2017), Heimberger (2019).
} 
a külföldi szektor megnövekedett hiánya tudja csak ellensúlyozni. Természetesen az egyes országok szintjén jelentős eltérések figyelhetők meg a szektorális bontás tekintetében. Különösen szembetűnő az északi és déli országok közötti eltérés: Németországban és Hollandiában például mind a magánszektor, mind a kormányzati szektor szufficites, ezzel szemben Olaszországban és Spanyolországban a külföld mellett részben a költségvetési deficit ellensúlyozza a magánmegtakarításokat.

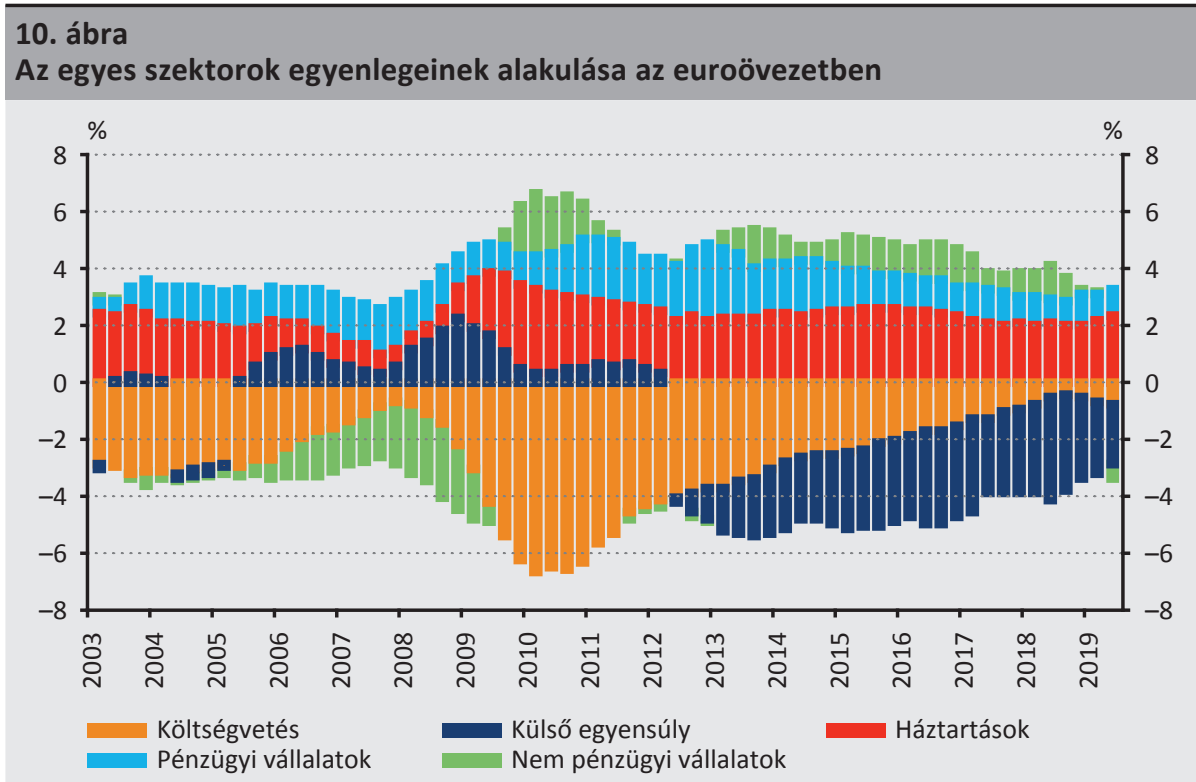

Megjegyzés: Négy negyedéves gördülö átlag. A külső egyensúly esetében a negativ érték a külföld eladósodását, azaz az eurozóna pénzügyi számláinak többletét jelenti.

Forrás: $E K B$

A spanyol gazdaságban a beruházások jelentős élénkülése volt megfigyelhető a válságot megelőzően, amelyhez a szükséges tőke nagy részét a külföldi szektor biztosította. A válságot megelőző időszakban jelentős mértékű beruházást hajtottak végre a nem pénzügyi vállalatok (2007-ben a GDP 30 százaléka), amellyel párhozamosan a háztartások csökkentették megtakarításaikat (11. ábra). A magánszektor nettó deficites pozíciójának következtében a GDP 10 százalékát megközelítő mértékű fizetésimérleg-deficitet ért el a spanyol gazdaság, ami a jelentős tőke- és áruimportnak volt a következménye.

A pénzügyi válság során a spanyol gazdaság - annak érdekében, hogy simítsa a viszszaesés negatív hatásait - átmenetileg jelentős költségvetési hiány mellett múködött. A válságot követően azonban teljes struktúra váltás történt Spanyolország szektorális egyenlegeiben: mind a nem pénzügyi vállalati szektor, mind a háztartási 
szektor nettó megtakarítói pozícióba került. Ennek hatására a GDP-arányos beruházás jelentős mértékben mérséklődött, az előző évtized átlagához képest jelenleg 3-4 százalékponttal alacsonyabb beruházási arány figyelhető meg. Ezzel párhuzamosan a fizetési mérleg a korábbi deficitből többletbe fordult, miközben a költségvetési hiány mértéke fokozatosan csökkent.

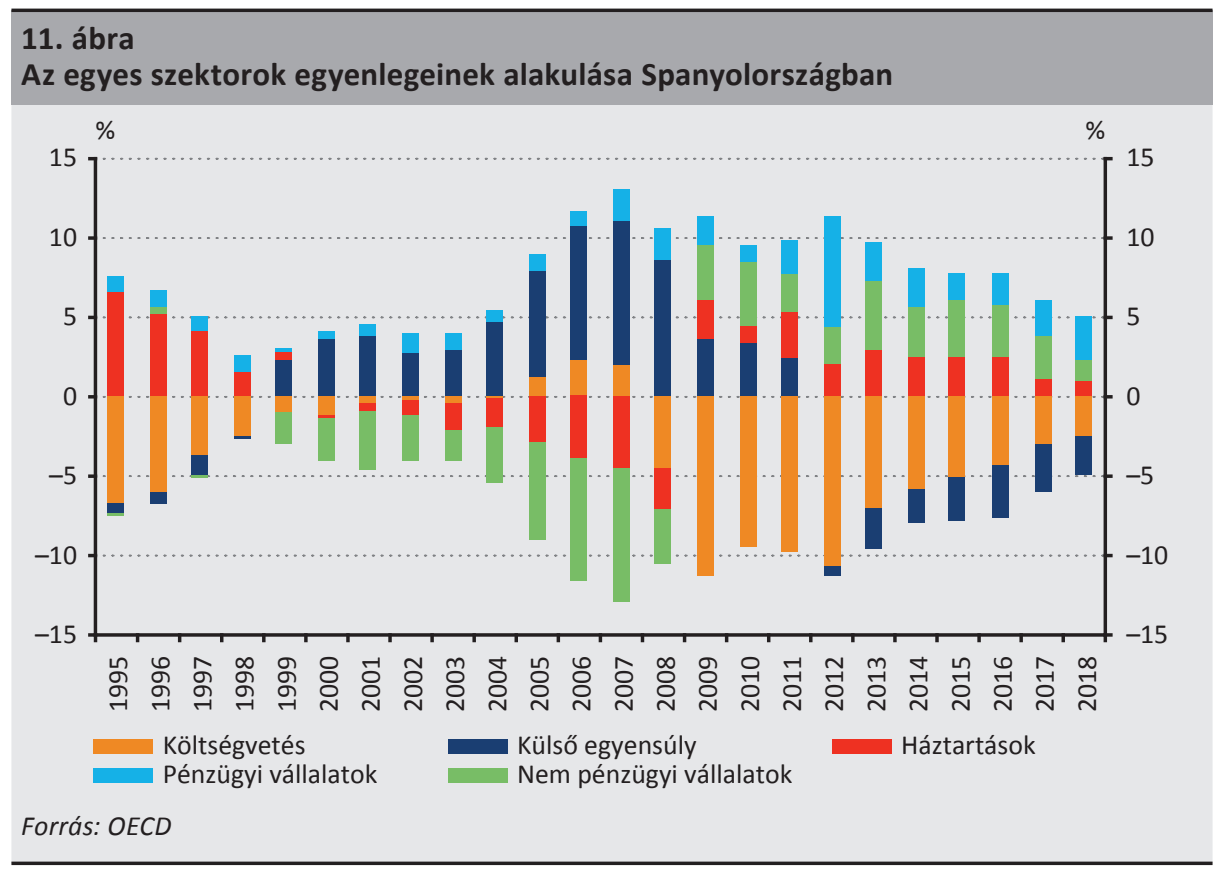

Németországban 2008 előtt a magánszektor nettó megtakarítói pozíciót vett fel. A válságot megelőző időszakban a magánszektor minden alszektorában nettó megtakarítói pozíció volt megfigyelhető, amely magas nettó exporttöbblettel társult (12. ábra). A szektorok egyenlegeinek ezen szerkezete pontosan tükrözi a német gazdaságról kialakult képet, amely szerint a meghatározó exporttöbblet mellett a német háztartások megtakarítása a GDP 5 százalékával bővül. A nem pénzügyi vállalatok nettó megtakarítói pozíciójának fenntartása mögött a GDP-arányos beruházásnak a 1990-es évek óta tartó folyamatos csökkenése áll, ami hozzájárult a potenciális kibocsátás növekedési ütemének mérséklődéséhez.

A pénzügyi válságot követő időszakban a német pénzügyi rendszer finanszírozói és/vagy beruházói szerepet vállal. 2012 után több, jelentős változás is megfigyelhető a szektorális egyenlegekben, amelyek eurozóna-szintú hatást gyakorolnak. Mindenekelőtt érdemes megemlíteni a szigorú, többletes költségvetés kialakítását, amely a GDP arányában is jelentős. Ennek hatására az export maradt a gazdaság legmeghatározóbb motorja, amelyet kiegészít a német pénzügyi vállalatok nettó 
kibocsátása is. Mivel a válságot követően a nem pénzügyi vállalatok jellemzően továbbra is megtakarítanak, a GDP-arányos beruházás továbbra is alulmúlja az 1980-as és 1990-es évek átlagát.

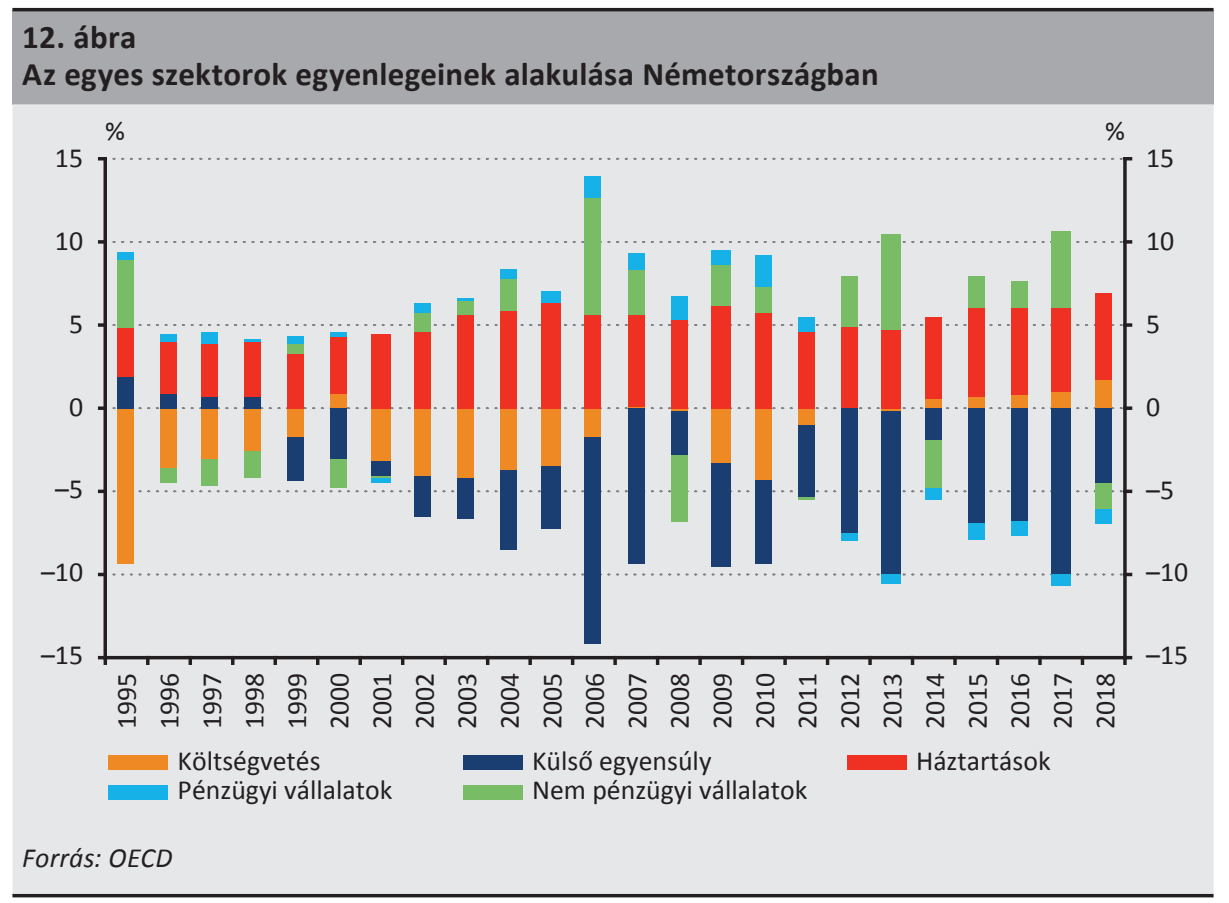

A maastrichti kritériumok szigorára építő fiskális szabályok és a lassuló globális gazdaság következtében csak jelentős magáneladósodás útján tartható fent érdemi növekedés. A szektorális egyenlegek számviteli összefüggése miatt bármilyen gazdaságpolitikai, illetve szabályozói lépés szükségszerűen szektorok közötti tradeoff mentén valósulhat csak meg. Figyelembe véve a maastrichti adósság- és deficitszabályokat, elmondható, hogy az eurozóna gazdasági kormányzásának felépítése jelen gazdasági kondíciók mellett nem tesz lehetővé növekedést támogató fiskális politikát. Ennek szükségszerű következménye, hogy jelentős magánszektorbeli pénzügyi stabilitási kockázatok felépülése nélkül, pusztán az exportvezérelt növekedés jelenthet alternatív növekedési modellt. Ez a modell elég jól múködött a múltban Németország és Hollandia számára, azonban az amerikai gazdaság protekcionista politikája és a kínai gazdaság lassulása mellett ennek fenntarthatósága kétséges.

A jelenleg érvényes költségvetési szabályok betartása negatív hatást gyakorol az aggregált keresletre. A jelentős külkereskedelmi többlet szintén visszahat a vállalatok versenyképességére, mivel a külföldi szektor finanszírozása a fiskális szigor mellett csak visszafogott bérnövekedés mellett maradhat fenn. Ennek következtében foko- 
zottan hiányos lesz a belső kereslet, amelynek hatására gyengébb lesz a növekedés, ezért a vállalatok még kevésbé ruháznak be, és a visszafogott növekedés miatt az adósságráta fenntartása érdekében még szigorúbb fiskális politika válik szükségessé.

\section{Az EKB döntéshozóinak álláspontja a gazdaságpolitikai ágak közötti koordinációról}

Mario Draghi, az Európai Központi Bank 2019. október végén, mandátumának lejártával távozó elnöke beszédeiben korábban is rendszeresen hangsúlyozta a fiskális politika jelentőségét. 2019 júniusában azonban a jegybankárok és akadémikusok szokásos éves fórumán, Sintrában tartott beszédében a korábbiaknál is határozottabban hívta fel a figyelmet annak fontosságára. A volt jegybankelnök kiemelte, hogy noha a válságot követő első szakaszban a monetáris és fiskális politika együttmúködött a gazdasági visszaesés fékezésében és visszafordításában, ezt követően az euroövezetben a két politika elvált egymástól, és a fiskális politika - szemben az Egyesült Államokkal - szigorított. Mario Draghi emellett kijelentette, hogy jelenleg nincs egyensúlyban a monetáris és a fiskális politika, ami hozzájárul a dezinflációhoz. Emiatt olyan közös fiskális politikai keretet kell kialakítani, amely lehetővé teszi a megfelelő mértékű fiskális stabilizálást az euroövezetben. Erre főként azért lenne szükség, mert noha vannak országok, amelyeknek lenne fiskális mozgásterük a jelenlegi szabályok mellett is, az esetleges lazítás átgyűrűző hatása a mozgástérrel nem rendelkező gazdaságokra túlságosan korlátozott. ${ }^{16}$

Egy későbbi beszédében Draghi azt hangsúlyozta, hogy az eurozónán belül problémát jelent a ciklusok földrajzi eltéréseinek simításában, hogy az Európai Stabilitási Mechanizmus (ESM) mögött nincs egyértelmű, közös, végső hitelező (backstop) az állampapírok piacára vonatkozóan, nincs közös banki betétbiztosítás, és egyelőre nincs érdemleges fiskális politikai koordináció sem az övezet szintjén. Az euroövezeti szintű ciklikus stabilizációval kapcsolatban elmondta, hogy az egyensúlyi reálkamatok az utóbbi években trendszerűen csökkentek. Ebben a környezetben a fiskális és monetáris politika közötti együttmúködés arányai megváltoznak. Az aktívabb fiskális politika enyhíthetné a monetáris politikára nehezedő stabilizáló terhet, és a negatív mellékhatások is mérséklődhetnének. Ám úgy látja, hogy az euroövezetben ezt egyáltalán nem ismerték fel, ami világosan látszik az adatokból: 2009 és 2019 között az átlagos elsődleges költségvetési egyenleg Japánban -5,7, az USA-ban -3,6 százalék, míg az euroövezetben +0,5 százalék volt. Draghi szerint a jegybankok kötelesek megszólalni, ha más politikák segíthetnek céljuk gyorsabb elérésében. ${ }^{17}$

${ }^{16}$ Twenty Years of the ECB's monetary policy. Speech by Mario Draghi, President of the ECB, ECB Forum on Central Banking, Sintra, 18 June 2019. https://www.ecb.europa.eu/press/key/date/2019/html/ecb. sp190618 ec4cd2443b.en.html. Letöltés ideje: 2019. december 9.

17 Stabilisation policies in a monetary union. Speech by Mario Draghi, President of the ECB, at the Academy of Athens, Athens, 1 October 2019. https://www.ecb.europa.eu/press/key/date/2019/html/ecb. sp191001_1 5d7713fcd1.en.html. Letöltés ideje: 2019. december 9. 
Draghi értékelése szerint jelenleg mérsékelten támogató az euroövezet fiskális politikája, azonban, tekintettel a romló gazdasági kilátásokra és a lefelé mutató kockázatokra, a fiskális mozgástérrel rendelkező országoknak időben és hatékonyan kellene cselekedniük. Emellett felhívta a figyelmet arra is, hogy minden sikeres monetáris unióban létezik egy központi fiskális kapacitás. Emiatt nagyon fontos, hogy az euroövezet esetében is létezzen egy megfelelő méretǔ kapacitás, amelyet egyfajta anticiklikus stabilizátorként lehetne használni. Jelenleg problémát jelent ugyanis, hogy a decentralizált fiskális politikák megfelelő koordinációja nagyon öszszetett feladat ${ }^{18}$.

Mario Draghi EKB-elnöki búcsúbeszédében megemlítette, hogy az euroövezetet a monetáris dominancia elvére építették, amelyhez szükséges, hogy a monetáris politika egyedül az árstabilitásra tudjon összpontosítani és soha ne legyen alárendelve a fiskális politikának. Ez azonban nem gátolja a monetáris politikát abban, hogy jelezze a kormányzatok felé, hogy kölcsönösen összehangolt politikákkal gyorsabban teljesíthető lenne az árstabilitási cél. A tőkepiaci unió megalkotása csökkentené azokat a stabilizációs feladatokat, amelyeket a központi fiskális kapacitásnak kellene kezelnie ${ }^{19}$.

Az Európai Központi Bank későbbi elnöke, Christine Lagarde 2019 szeptemberében, az Európai Parlament gazdasági és monetáris ügyek bizottsági meghallgatásán kiemelte, hogy az eurozóna gazdaságának ciklikus stabilizálásában fontos lenne a fiskális politikával való kooperáció, és hasznos lenne egy központosított fiskális kapacitás kialakítása ${ }^{20}$. Emellett arra is felhívta a figyelmet, hogy a jelenlegi fiskális szabályokat egyszerűbbé és hatékonyabbá kell tenni. Egy későbbi nyilatkozatában pedig elődjéhez hasonlóan hangsúlyozta, hogy a mozgástérrel rendelkező országoknak aktívabb fiskális politikát kellene folytatniuk. Ráadásul Draghival szemben, aki mindig tartózkodott konkrét országok megnevezésétől, Lagarde nyíltan kiemelte Németországot és Hollandiát mint olyan országokat, amelyeknek fiskális lazítást kellene végrehajtaniuk a beruházások ösztönzése érdekében. Kritikusan megjegyezte azt is, hogy nincs kellő szolidaritás az övezetben: miközben közös pénzt használnak, nincs közös költségvetési politika (Lagarde 2019).

Az EKB döntéshozói közül a holland Klaas Knot is arról beszélt 2019. októberben, hogy a Gazdasági és Monetáris Unió (EMU) megerősítésére van szükség, további lépések nélkül ugyanis a monetáris politika növekedésösztönző intézkedései korlá-

${ }_{18}$ Introductory Statement, Press Conference. Mario Draghi, President of the ECB, Frankfurt am Main, 24 October 2019. https://www.ecb.europa.eu/press/pressconf/2019/html/ecb.is191024 78a5550bc1.en.html. Letöltés ideje: 2019. december 9.

${ }^{19}$ Remarks by Mario Draghi, at the farewell event in his honour. Frankfurt am Main, 28 October 2019. https:// www.ecb.europa.eu/press/key/date/2019/html/ecb.sp191028 7e8b444d6f.en.html. Letöltés ideje: 2019. december 9.

${ }^{20}$ Draft Report on the Council recommendation on the appointment of the President of the European Central Bank. European Parliament, Committee on Economic and Monetary Affairs, 29 August 2019. http://www. europarl.europa.eu/doceo/document/ECON-PR-639816_EN.pdf. Letöltés ideje: 2019. december 9. 
tozottá válhatnak. Véleménye szerint a monetáris és fiskális politikának egy irányba kellene lépnie, a tapasztalatok ugyanis azt mutatják, hogy a monetáris politika gyorsabban és kisebb mellékhatások mellett érheti el céljait, ha összhangban van a fiskális politikával (Knot 2019b). Luis de Guindos, az Európai Központi Bank alelnökének is az az álláspontja, hogy az euroövezetnek egy központi, független fiskális eszközre van szüksége, a jelenlegi keretrendszer ugyanis nem hatékony, és nem egészíti ki megfelelően az EKB monetáris politikáját. Guindos érvelése szerint egy központi eszköz a nemzeti fiskális politikákat is támogatná (Guindos 2019).

Az Európai Központi Bank 2019 szeptemberében bejelentett monetáris lazító csomagját több döntéshozó is bírálta, és többen hangsúlyozták, hogy a fiskális politikának határozottabban kellene támogatnia a monetáris politikát. Emellett egyre többen hívják fel a figyelmet arra, hogy egy érdemi, eurozóna-szintű fiskális kapacitás kialakítására is szükség lenne, amely övezeti szinten lenne képes simítani a ciklusokat, és ezáltal hosszú távon stabilizálhatnák az euroövezet gazdaságát. Egyelőre azonban a gazdaságpolitikai diskurzusból nem körvonalazódik egyetértés és támogatás azon országok részéről, ahol a kapacitás rendelkezésre áll. Emiatt a gazdaságpolitikai ágak közötti vita elhúzódása várható. Mivel a fiskális politika aktív szerepe vagy a közös fiskális kapacitás az érvényes szabályok újradefiniálását is eredményezné, nem várható gyors reform és a monetáris politika támogatása. ${ }^{21}$

\section{6. Összegzés}

Az elmúlt évtizedekben mind a gazdasági növekedést, mind az inflációs folyamatokat tekintve érdemi mérséklődés volt megfigyelhető az euroövezetben. Ennek eredményeként a maastrichti kritériumokban megfogalmazott és a fiskális szabályokba beépített számszerű értékek közül egyesek mára gyakorlatilag érvényüket veszítették, ami feszültséget okoz a gazdaságpolitikai döntéshozatal során. A válságot követő ultralaza monetáris politikai irányultság ellenére a monetáris politika több régióban sem tudta kellő mértékben támogatni a magánszektor beruházásait és az aggregált keresletet, így a nehézségek az utóbbi években még látványosabbá váltak. Az utóbbi időszakban az EKB döntéshozói között is egyre élesebb ellentétek kerültek felszínre a gazdaságpolitikai ágak közötti optimális feladatmegosztást illetően. Az Európai Központi Bank legutóbbi, 2019 szeptemberében bejelentett monetáris lazító csomagját több döntéshozó is bírálta, kiemelve, hogy a monetáris politika már elérte korlátait, és a jelenlegi környezetben minimális lehet a további lépések

\footnotetext{
${ }^{21}$ Ezt a kilátást erősíti Marco Buti és bizottsági munkatársai 2019. novemberi válasza a Bizottság potenciális kibocsátásra vonatkozó becsléseinek bírálatára, ami azt sugallja, hogy nem látnak lehetőséget és valójában szükségét sem annak, hogy lényegesen változtassanak a módszertanon (Buti et al. 2019). Noha Buti a múlt év végével távozott a Bizottság főigazgatói posztjáról, feltehetjük, hogy az idézett cikk egyelőre továbbra is reprezentálja a szakmai álláspontot az intézményen belül. Mindezek mellett Buti (2020) leköszönését követően elismeri, hogy a görög válság hatására az Európai Unió többi országának problémáját is fiskális jellegűnek kezelték, amelyet hibának nevez, illetve felhívja a figyelmet a fiskális politika aktívabb szerepvállalásának szükségességére a monetáris politika mellett.
} 
gazdaságélénkítő hatása. Ezzel párhuzamosan egyre többen hangsúlyozták, hogy a fiskális politikának határozottabban kellene támogatnia a monetáris politikát és ezzel a gazdasági növekedést. Emellett egyre többen hívják fel a figyelmet arra, hogy egy érdemi, eurozóna-szintű fiskális kapacitás kialakítására is szükség lenne, amely övezeti szinten lenne képes simítani a ciklusokat, és ezáltal hosszú távon tudná stabilizálni az euroövezet gazdaságát.

Noha a fiskális szabályok változtak, és az intézményi reformokban is látszik némi előrelépés, egyelőre egyik intézkedés megvalósítására sem mutatkozik érdemi gazdaságpolitikai hajlandóság. Az egyes tagállamok által benyújtott, jövő évi költségvetési javaslatok alapján elmondható, hogy a közeljövőben továbbra sem várható érdemi fiskális élénkítés az eurozónában. Egyes országok ellenállása mellett a koordinált fiskális expanzió lehetőségét a maastrichti elven alapuló fiskális szabályok is korlátozzák. Emellett további problémát jelent, hogy az euroövezeti fiskális szabályok nem veszik figyelembe az egyes gazdasági szektorok közötti összefüggéseket sem. Az euroövezeten belül a déli országok prociklikus gazdaságpolitikája jelenleg nem teszi lehetővé egy esetleges válság megelőzését, illetve kezelését. Ezzel szemben az északi országok gazdasági kondíciói ugyan lehetővé tennék egy koordinált fiskális expanzió elindítását, azonban ezekben a tagállamokban nincs ilyen irányú szándék, noha egyes elemzések alapján a tagországok többségének költségvetési egyenlege az adósságráta változatlansága mellett jelentős mértékű lazításra adna mozgásteret. Előretekintve célszerű lehet a jelenleg is érvényben lévő maastrichti kritériumok, a fiskális szabályok és ezzel párhuzamosan az egyes gazdaságpolitikai ágak közötti feladatmegosztás újragondolása.

\section{Felhasznált irodalom}

Bagdy Ábel - Füstös Krisztina - Szalai Zoltán (2020): Hogyan tovább Eurozóna: intézményi fejlödési irányok. In: Virág Barnabás (szerk.): Fenntartható felzárkózás euróval - Hogyan újítsuk meg a maastrichti kritériumokat? Magyar Nemzeti Bank, pp. 121-146.

Balázs Flóra - Lehmann Kristóf - Szalai Zoltán (2020): A maastrichti kritériumok hiányosságai. In: Virág Barnabás (szerk.): Fenntartható felzárkózás euróval - Hogyan újítsuk meg a maastrichti kritériumokat? Magyar Nemzeti Bank, pp. 91-120.

Ball, L. (2015): Monetary Policy for a High-Pressure Economy. https://pdfs.semanticscholar.org/3ecf/cdff1148c703d50a1e992290867e007a96db.pdf. Letöltés ideje: 2019. december 9.

Barwell, R. - Burrows, O. (2011): Growing Fragilities? Balance Sheets in the Great Moderation. Financial Stability Paper No 10, Bank of England. https://www.bankofengland.co.uk/-/media/boe/files/financial-stability-paper/2011/growing-fragilities-balance-sheets-in-the-great-moderation. Letöltés ideje: 2019. december 9. 
Bibow, J. - Terzi, A. (2007): Introduction: Euroland and the World Economy - Global Player or Global Drag? In: Bibow, J. - Terzi, A.: Euroland and the World Economy - Global Player or Global Drag? Macmillan, pp. 1-11. https://doi.org/10.1057/9780230377554_1

Blanchard, O. - Summers, L.H. (1986): Hysteresis and the European unemployment problem. In: Fisher, S. (ed.): NBER Macroeconomics Annual 1986, Vol. 1. MIT Press, pp. 15-90. https://doi.org/10.3386/w1950

Blanchard, O. - Leigh, D. (2013): Growth forecast errors and fiscal multipliers. IMF Working Papers, No. 13/1, Washington, D.C. https://doi.org/10.5089/9781475576443.001

Buti, M. - Carnot, N. - Hristov, A. - Mc Morrow, K. - Roeger, W. - Vandermeulen, V. (2019): Potential output and EU fiscal surveillance. VOXEU, 23 September. https://voxeu.org/ article/potential-output-and-eu-fiscal-surveillance. Letöltés ideje: 2020. január 31.

Buti, M. (2020): Riding through the storm: Lessons and policy implications for policymaking in EMU. VOEXEU, 12 January. https://voxeu.org/article/lessons-and-policy-implications-policymaking-emu. Letöltés ideje: 2020. február 5.

Caiani, A. - Godin, A. - Caverzasi, E. - Gallegati, M. - Kinsella, S. - Stiglitz, J.E. (2016): Agent based-stock flow consistent macroeconomics: Towards a benchmark model. Journal of Economic Dynamics and Control, 69(August): 375-408. https://doi.org/10.1016/j. jedc.2016.06.001

De Grauwe, P. - Ji, Y. (2019): Rethinking fiscal policy choices in the euro area. VOX, CEPR Policy Portal, 14 October. https://voxeu.org/article/rethinking-fiscal-policy-choices-euro-area. Letöltés ideje: 2019. december 9.

Fatas, A. - Summers, L.H. (2018): The permanent effects of fiscal consolidations. Journal of International Economics, 112(May): 238-250. https://doi.org/10.1016/j.jinteco.2017.11.007

Fleming, S. - Khan, M. (2019): EU finance ministers approve separate 'eurozone budget' tool. Financial Times, 10 October. https://www.ft.com/content/1cf66b48-eb35-11e9-a2403b065ef5fc55. Letöltés ideje: 2019. december 9.

Godley, W. - Lavoie, M. (2007): Monetary Economics: An Integrated Approach to Credit, Money, Income, Production and Wealth. London: Palgrave MacMillan.

Guindos, L. (2019): Euro Area Needs a Central Fiscal Instrument, ECB's Guindos says. Bloomberg, 26 October. https://www.bloomberg.com/news/articles/2019-10-26/euro-area-needs-a-central-fiscal-instrument-ecb-s-guindos-says. Letöltés ideje: 2019. december 9.

Heimberger, P. - Kapeller, J. (2017): The performativity of potential output: pro-cyclicality and path dependency in coordinating European fiscal policies. Review of International Political Economy, 24(5). https://doi.org/10.1080/09692290.2017.1363797 
Heimberger, P. (2019): What is structural about unemployment in OECD countries. Review of Social Economy. https://doi.org/10.1080/00346764.2019.1678067

HSBC (2019): Eurozone fiscal policy - More a water pistol than a bazooka. Report of HSBC Global Research, 22 October.

Knot, K. (2019a): Dutch governor attacks ECB's new stimulus. Central Banking, 13 September. https://www.centralbanking.com/central-banks/monetary-policy/monetary-policy-decisions/4429901/dutch-governor-attacks-ecbs-new-stimulus. Letöltés ideje: 2019. december 9.

Knot, K. (2019b): Opening remarks by Klaas Knot. At the panel "The Advanced Countries: Economic Challenges for the Medium Term" during the G30 34th International Banking Seminar, Washington, 20 October. https://www.dnb.nl/en/binaries/AC_tcm47-386006. pdf. Letöltés ideje: 2019. december 9.

Kregel, J. (2010): An Alternative Perspective on Global Imbalances and International Reserve Currencies. Levy Economics Institute of Bard College. http://www.levyinstitute.org/pubs/ ppb_116.pdf. Letöltés ideje: 2019. december 9.

Kregel, J. (2015): Europe at the crossroads: financial fragility and the survival of the single currency. Levy Economics Institute of Bard College. http://www.levyinstitute.org/pubs/ pn_15_1.pdf. Letöltés ideje: 2019. december 9.

Lagarde, C. (2019): Lagarde hits out at Germany and Netherlands on public spending. Financial Times, 30 October. https://www.ft.com/content/eb8dae8c-fb14-11e9-a35436acbbb0d9b6. Letöltés ideje: 2019. december 9.

Ledesma, L. - Thirlwall, A. (2000): Is the natural rate exogenous? BNL Quarterly Review, 53(215): 433-445.

Lehmann Kristóf - Szalai Zoltán - H. Váradi Balázs (2017): Új szelek a gazdaságpolitikában. Szakmai cikk, Magyar Nemzeti Bank. https://www.mnb.hu/letoltes/lehmann-kristof-szalai-zoltan-h-varadi-balazs-mnbhonlapra.pdf. Letöltés ideje: 2019. december 9.

Lehmann Kristóf - Palotai Dániel (2019): A maastrichti kritériumok: 20. századi szabályok a 21. században. Szakmai cikk, Magyar Nemzeti Bank. https://www.mnb.hu/letoltes/lehmann-kristof-palotai-daniel-a-maastrichti-kriteriumok-harom-evtized-tukreben-2-cikk. pdf. Letöltés: ideje: 2019. december 9.

Nagy Márton - Virág Barnabás (2017): Felzárkózás az eurozónában - csakis megfelelö felkészültséggel teljesithető. Szakmai cikk, Magyar Nemzeti Bank. https://www.mnb.hu/ letoltes/nagy-marton-virag-barnabas-felzarkozasi-az-eurozonaban-frissitett.pdf. Letöltés ideje: 2019. december 9. 
Nagy Olivér - Szalai Zoltán - H. Váradi Balázs (2020): A maastrichti kritériumok-feltételek és feltevések. In: Virág Barnabás (szerk.): Fenntartható felzárkózás euróval - Hogyan újítsuk meg a maastrichti kritériumokat? Magyar Nemzeti Bank, pp. 19-38.

Okun, A. (1973): Upward Mobility in a High-Pressure Economy. Brookings Papers on Economic Activity, 1973(1): 207-261. https://doi.org/10.2307/2534087

Orphanides, A. - Williams, J.C. (2005): The Decline of Activist Stabilization Policy: Natural Rate Misperceptions, Learning and Expectations. Journal of Economic Dynamics and Control, 29(11): 1927-1950. https://doi.org/10.1016/j.jedc.2005.06.004

Parenteau, R. (2010): Minsky and the Eurozone Predicament: Transcending the Dismal Science. Presented at the 19th Annual Hyman P. Minsky Conference, After the Crisis- Planning a New Financial Structure, New York, N.Y., April 15.

Powell, J.H. (2018): Monetary Policy in a Changing Economy. Speech at Jackson Hole conference, Wyoming, 24 August. https://www.federalreserve.gov/newsevents/speech/powell20180824a.htm. Letöltés ideje: 2019. december 9.

Tóth G. Csaba (2011): Adósságdinamika és fenntarthatóság. Statisztikai Szemle, 89(12): 1242-1268.

Weidmann, J. (2019): ECB Governing Council has gone too far. Interview with the BILD newspaper, 14 September. https://www.bundesbank.de/en/press/interviews/-ecb-governing-council-has-gone-too-far--806872. Letöltés ideje: 2019. december 9. 